\title{
Review \\ Biological and Agronomic Traits of the Main Halophytes Widespread in the Mediterranean Region as Potential New Vegetable Crops
}

\author{
Tiziana Lombardi 1,2 (D) Andrea Bertacchi 1,2 ${ }^{(D)}$, Laura Pistelli 1,2,3 ${ }^{(D}$, Alberto Pardossi 1,2,3 $(\mathbb{D}$, \\ Susanna Pecchia 1,2,3,*(D), Annita Toffanin 1,2,3 and Chiara Sanmartin 1,2,*(D)
}

Citation: Lombardi, T.; Bertacchi, A.; Pistelli, L.; Pardossi, A.; Pecchia, S.; Toffanin, A.; Sanmartin, C. Biological and Agronomic Traits of the Main Halophytes Widespread in the Mediterranean Region as Potential New Vegetable Crops. Horticulturae 2022, 8, 195. https://doi.org/ 10.3390/horticulturae8030195

Academic Editors: Silvana Nicola, Katerina Grigoriadou

and Christoph Schunko

Received: 18 January 2022

Accepted: 21 February 2022

Published: 23 February 2022

Publisher's Note: MDPI stays neutral with regard to jurisdictional claims in published maps and institutional affiliations.

Copyright: (C) 2022 by the authors. Licensee MDPI, Basel, Switzerland. This article is an open access article distributed under the terms and conditions of the Creative Commons Attribution (CC BY) license (https:// creativecommons.org/licenses/by/ $4.0 /)$.
1 Department of Agriculture, Food and Environment, University of Pisa, Via Del Borghetto 80, 56124 Pisa, Italy; tiziana.lombardi@unipi.it (T.L.); andrea.bertacchi@unipi.it (A.B.); laura.pistelli@unipi.it (L.P.); alberto.pardossi@unipi.it (A.P.); annita.toffanin@unipi.it (A.T.)

2 CIRSEC Centre for Climate Change Impact, University of Pisa, Via del Borghetto 80, 56124 Pisa, Italy

3 Interdepartmental Research Center, Nutraceuticals and Food for Health, University of Pisa, Via del Borghetto 80, 56124 Pisa, Italy

* Correspondence: susanna.pecchia@unipi.it (S.P.); chiara.sanmartin@unipi.it (C.S.)

\begin{abstract}
Salinity is one of the oldest and most serious environmental problems in the world. The increasingly widespread salinization of soils and water resources represents a growing threat to agriculture around the world. A strategy to cope with this problem is to cultivate salt-tolerant crops and, therefore, it is necessary to identify plant species that are naturally adapted to high-salinity conditions. In this review, we focus our attention on some plant species that can be considered among the most representative halophytes of the Mediterranean region; they can be potential resources, such as new or relatively new vegetable crops, to produce raw or minimally processed (or readyto-eat) products, considering their nutritional properties and nutraceuticals. The main biological and agronomic characteristics of these species and the potential health risks due to mycotoxigenic fungi have been analyzed and summarized in a dedicated section. The objective of this review is to illustrate the main biological and agronomical characteristics of the most common halophytic species in the Mediterranean area, which could expand the range of leafy vegetables on the market.
\end{abstract}

Keywords: salt tolerance; Salicornia; Suaeda; Atriplex; Portulaca; novel food; hydroponic cultivation; mycotoxigenic fungi

\section{Introduction}

The increasing salinization of both soils and water resources, which is mainly due to anthropic activity, has created a new interest in salt tolerant plants as potential crops for saline environments [1,2].

Halophytes are the plants with the highest level of salt tolerance resulting from several morphological, physiological, and biochemical traits, such as osmotic adjustment; ion compartmentalization and homeostasis; detoxification of reactive oxygen species; salt secretion; and other mechanisms that are not yet fully understood [3-5]. Halophytes can survive in very saline soils and exploit water resources of moderate-to-high salinity. The optimal salinity for the growth for most halophytes ranges from 50 to $250 \mathrm{mM} \mathrm{NaCl}$; however, they can grow and produce as much as conventional crops even when irrigated with seawater, so with a molarity greater than $500 \mathrm{mM}$ [6]. In general, halophytes are highly versatile plants and, in addition to their role in coastal-area preservation and as valuable scientific models for the investigation of salt-tolerance mechanisms, their exploitation as food and non-food crops could be a winning strategy in a salinizing world.

The cultivation of halophytes under greenhouse conditions-either in soil or in a soil-less system —or in an open field, to produce raw or minimally processed vegetables 
(i.e., ready-to-eat or fresh-cut products), in particular for gourmet cuisine, is of growing interest [7-9]. The edible parts of these species are appreciated due to their salty taste and high content in antioxidant compounds and essential nutrients (minerals, vitamins amino acids and/or fatty acids) [10,11]. Halophytes also contain ingredients of functional foods and active principles for medicinal supplements [12-15].

In the Mediterranean regions, the most abundant halophytes are found mainly in medium-high marshy areas; in most cases, these are directly connected to intertidal areas and are subject to sea water flooding. The floristic composition of these environments is closely linked to the topography and seasonal fluctuations in salinity, which can reach very high values-sometimes higher than that of sea water in the period of maximum evapotranspiration. The hyper-halophilous communities are dominated by therophytes or chamaephytes, annual or perennial shrubs, or grasses, while the sub-halophilous ones are characterized by hemicryptophytes and geophytes of different families. Among the typical plants, we can include many species of Amaranthaceae, such as Salicornia spp.; Suaeda vera J. F. Gmel. and S. maritima (L.) Dumort.; Halimione portulacoides (L.) Aellen; Soda inermis Fourr. and Atriplex spp.; and some species of Poaceae such as Puccinellia distans (Jacq.) Parl., Sporobolus aculeatus (L.) P. M. Peterson, Thinopyrum acutum (DC.) Banfi, and Hordeum maritimum Huds. These are often associated with other halotolerant species, including Limbarda crithmoides (L.) Dumort.; Galatella tripolium (L.) Galasso, Bartolucci and Ardenghi; Artemisia caerulescens L., Juncus spp.; Limonium spp.; and Plantago coronopus L.

The objective of this review is to illustrate the main biological and agronomical characteristics of the most common halophytic species in the Mediterranean area, which could expand the range of leafy vegetables on the market.

\section{Halophytes: Definition and Complexity}

Halophytes represent an ancient and remarkable ecological group of annual or perennial plants with very complex features, whose definition and classification are still not univocal and often controversial [16]. The species belonging to this group are very different from an ecological, morpho-physiological, and taxonomic point of view; therefore, their definition can be subjective and vary a lot in the literature according to the different interpretations. However, following the most popular definition used in the literature, halophytes can be identified as plants that grow naturally, and complete their life cycle in environments that contain a higher salt content than most plant species can tolerate [17].

The occurrence of halophytism is widespread throughout the plant kingdom and appears to have evolved several times, lending support to the concept that many glycophytes may have halophyte genes permanently switched off, but under mutagenesis, may revert to halophytism [18]. In fact, all four plant kingdoms contain members that are adapted to saline habitats; however, they occur in greater numbers among the thallophytes, such as red and brown algae, and terrestrial or aquatic spermatophytes. These plants are mainly distributed in arid or semi-arid inlands and saline wetlands along the tropical and sub-tropical coasts, as well as in temperate zones [17].

Halophyte plants and their natural habitats have attracted the attention of many naturalists and writers since very remote times. Allusions to salt-tolerant plants in saline soils along the banks and margins of salty waters date back to the mid-1500s, and data on halophytes were already very consistent in the 1700s. In Hortus Cliffortianus and Species Plantarum, when describing plants, Limneo often provides information on the salinity of their habitat [19].

The introduction of the word 'halophyte' probably dates to the Russian botanist Peter Simon Pallas; in the early 1800s, he wrote that species of Salicornia, Salsola, Suaeda and related plants, all previously included in the Chenopodiaceae and now included in Amaranthaceae family following APG classification, "must be united under what he believes is an appropriate name for Halophyta" [20]. In contrast to the term 'halophyte', the name 'glycophyte' was proposed by Stocker (1928) [21] for plants growing in soils with a low salt content. Most cultivated plants are glycophytes. Given the great biodiversity of these plants and the difficulty in distinguishing between salt-tolerant glycophytes and 
halophytic species, estimating the number of halophyte species and their diffusion is more difficult.

According to Houérou (1993) [22] and Glenn et al. (1999) [23], there are about 6000 species of terrestrial and marine plants in the world that are classified as halophytes. These represent $2 \%$ of the angiosperms, and some of them are under continuous taxonomic revision. Of these, approximately 1100 are widespread in the Mediterranean basin, with a wide range of levels of tolerance to salinity. Actually, it is possible to refer to the online database of salt-tolerant plants, namely eHALOPH [24], which is constantly updated. It is based on the records of Aronson (1989) [25] and includes plants that tolerate a soil electrical conductivity (EC) of at least about $8 \mathrm{dS} / \mathrm{m}$, corresponding to about $80 \mathrm{mM} \mathrm{NaCl}$ concentrations [26]. The eHALOPH Halophyte Database currently identifies more than 1500 species as salt-tolerant, albeit without labelling them as 'halophyte'. Other authors report a greater number of halophytic species but, despite the difference, most detailed lists represent only $0.5 \%$ of all angiosperms [27].

The complexity of the halophyte group is also linked to the multitude of ecosystems that species can contribute to from all over the world. These habitats can be either natural or non-natural, and include semi-deserts, salt meadows, brackish swamps, mangrove forests, irrigated lands, and even urban areas. Many of the natural habitats are highly threatened due to both natural and anthropogenic factors, such as urbanization, tourism, and pollution. The effects of climate change are increasingly adding to the threats to which natural halophytic habitats and vegetation are exposed. Many saline habitats are likely to disappear due to rising sea levels, as these communities generally do not have the ability to relocate to more inland sites. The conservation value of these ecosystems has recently been assessed in the EU project 'Red List of habitats', which are classified as 'Near Threatened' (Arctic coastal salt marsh, and Mediterranean and Black Sea coastal salt marsh), 'Endangered' (Baltic coastal meadow) or 'Vulnerable' (Atlantic coastal salt marsh) [28]. In addition, many countries are facing the loss of agricultural soil due to secondary salinization resulting from irrigation, fertilization, and climate change. Nearly $20 \%$ of the total irrigated land area (45 million hectares) is already affected by salinization [29]. In regions with saline soils, halophytes could be alternative crops to glycophytes to produce food, forage, and fibers, and for industrial purposes. Moreover, when halophytes are grown as companion plants of glycophytes, the negative effect of salinity is alleviated by the uptake of toxic ions by the former species, as found by Colla et al. (2006) [30] and Karakas et al. 2021 [31].

\section{Classification of Halophytes}

Halophytes are very peculiar both physiologically and morphologically, and in some cases, are of great phytogeographic interest. It is, therefore, not surprising that they have been the subject of many studies in various fields of botany, and still are today.

The survival of halophytes is strongly influenced by the salinity in the root zone or, sometimes also by salt spray, as this can happen in saline semi-deserts, in brackish marshes, or on beaches. These types of environments have both negative effects on plants, due to the high osmotic pressure of the soil solution and the toxic effect of salt, and positive ones, as it reduces competition with other plants and may prevent diseases and parasites [32].

When a plant's response to salinity is considered, we usually refer to $\mathrm{NaCl}$, although halophytes are also strongly influenced by other salts, such as $\mathrm{MgSO}_{4}, \mathrm{NaSO}_{4}$ or $\mathrm{KCl}$. Halophytes can be also described as plants that survive in environments where the salt concentration is around $200 \mathrm{mM} \mathrm{NaCl}$ or more [33]. For example, the most salt-tolerant halophytes, such as Suaeda salsa, can complete their life cycle in soils containing 200 to $500 \mathrm{mM} \mathrm{NaCl}$ [34]. Many studies have also shown that suitable high salt concentrations can enhance the growth of halophytes in comparison with low or negligible salinity $[35,36]$. This is proven at both the morphological and physiological level, with a greater biomass accumulation and better seed quality [37], and a higher photosynthetic efficiency [38,39].

By contrast, glycophytes have a limited tolerance to salinity, showing significant reductions in biomass under saline conditions. Among the glycophytes, two types are 
described based on their degree of sensitivity: salt-sensitive and salt-tolerant. Glycopyhytes include species, such as rice or soybean, that can suffer irreparable damage starting from very low concentrations (less than $\mathrm{NaCl} 50 \mathrm{mM}$ ), and others, such as barley or beets, that can tolerate much higher $\mathrm{NaCl}$ concentrations (even those close to $200 \mathrm{mM}$ ) [3]. From the morpho-functional point of view, no single factor is of major importance for the ability to survive at high $\mathrm{NaCl}$ salinity. Therefore, there are no peculiar characteristics that univocally define all the halophytic species, being a very heterogeneous and systematically complex group. The combination of several mechanisms often enhances the salt tolerance of individual species [40].

However, the evolution of multiple specific morpho-anatomical adaptations and functional characteristics is evident, aimed at fighting the saline environment and even benefiting from it. These adaptations are mostly related to the prevention of leaf water loss by transpiration, with dilution of the salts absorbed in excess or, in some cases, with their excretion. These characteristics are found mainly in the leaves and stems, since they are the plant organs most rigorously exposed to environmental conditions. Among the most important characteristics may be the reduction or absence of leaves, the abundance of glandular trichomes or saline glands, the greater development of supporting tissues, the development of atypical secondary growth, and leaf succulence. Typical succulent halophytes are, for example, species of Salicornia and Sarcocornia; these are two very interesting genera that appeared in Eurasia in the Middle Miocene period, and that have long represented difficulties for taxonomists due to their growth form with very small leaves and flowers. Although the response of halophytes to the multiple stressors of saline environments is well known (Figure 1), their classification in relation to the total number of flowering plants [41] continues to be very uncertain.

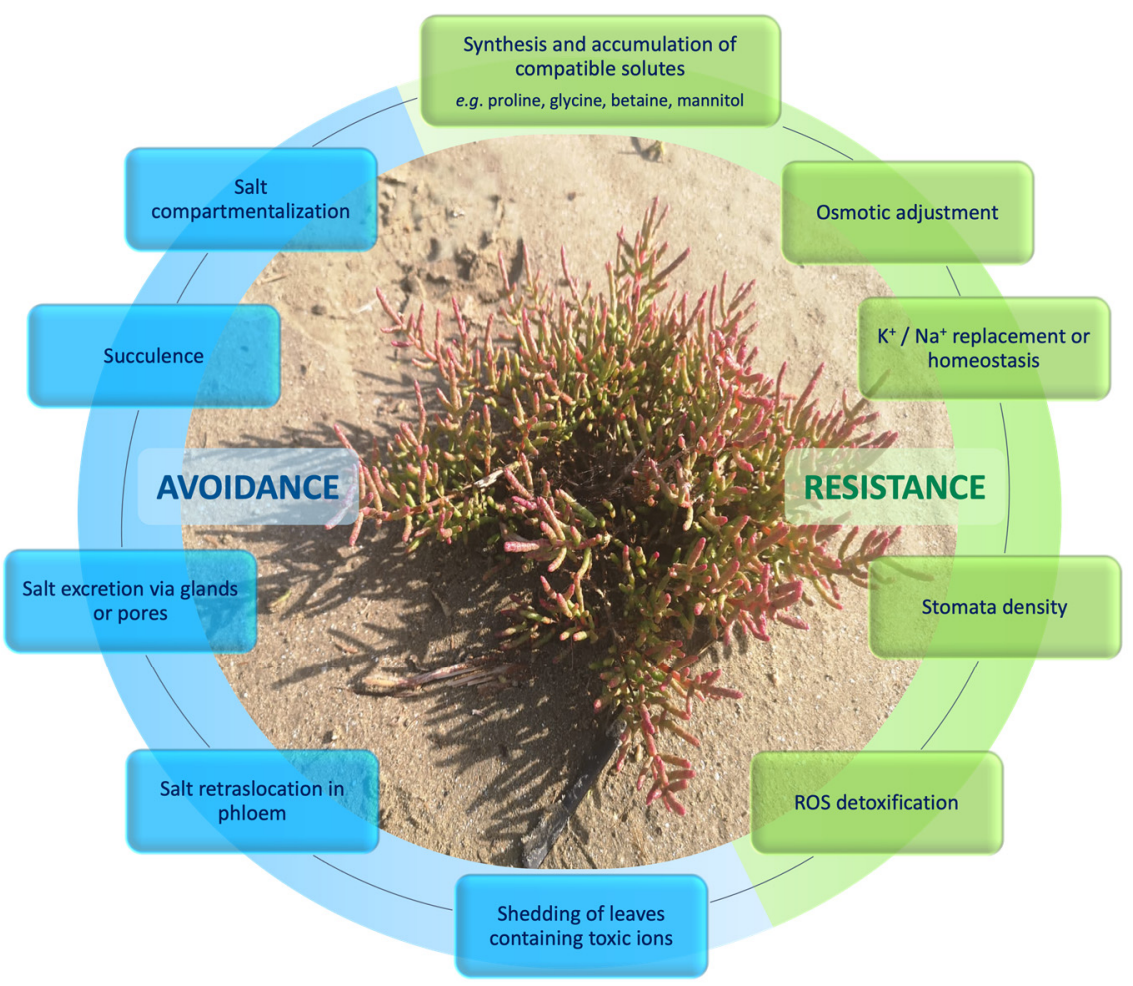

Figure 1. Response mechanisms to salinity stress by halophytic plants. Photo credit: Tiziana Lombardi.

As previously anticipated, due to their taxonomic and ecological complexity, even today, there is no consensus on a univocal definition. It is, therefore, difficult to draw a complete list of halophyte species, partly due to the problem of defining the lower limit of salt tolerance at which a plant should be considered a halophyte. Of course, this difficulty 
is reflected at the environmental level, in the vegetational subdivisions and zonation of communities dominated by halophyte species.

Halophytes are classified in various ways based on multiple factors, such as general ecological behaviour and distribution; plant growth response to salinity; salt intake rate; the presence or absence of saline glands, physiotype, etc. [32].

\subsection{Response to Internal Salt Content}

One of the first proposed classifications for flowering plants was based on their response to internal salt content, and divides halophytes into salt-regulating or and saltaccumulating types [42]. Based on their internal salt contents, halophytes were later also classified as excluders versus includers [17].

\subsection{Eco-Physiological Aspects}

Eco-physiological aspects can be used to differentiate the halophytes in obligate, facultative, and habitat-indifferent species [17]. This classification is based on what Ingram introduced in 1957, albeit without any definition of "low", "moderate", and "high" salinity. All three types of halophytes have better growth and development than glycophytes in saline environments [17].

- Obligate halophytes, mostly the Amaranthaceae members, are species with optimal growth at moderate or high salinity $(\mathrm{NaCl} 0.1-5 \%)$; they cannot grow at lower salinity, as they require salt as part of their nutrition to activate or de-activate several salt-sensitive enzymes. These species frequently exhibit an activation of these enzymes, both at very low $\mathrm{Na}^{+}$concentrations (below the physiological optimum) and at seawater $\mathrm{Na}^{+}$concentrations (considered excessive).

- Facultative halophytes are plants with the ability to grow on salty soils, but their optimal growth is observed in low-salt or non-saline conditions. Many dicotyledons such as Aster tripolium, Chenopodium quinoa, Glaux maritima, and Plantago maritima, but also some Poaceae, Cyperaceae and Juncaceae, belong to this group.

- Habitat-indifferent halophytes normally grow on salt-free substrates, but in saline conditions they thrive better than sensitive species. This group includes the plants that can live in disturbed or stable habitats. In some of these, such as Festuca rubra, Agrostis stolonifera and Juncus bufonius, there are significant genetic and morphological differences between the populations living on salty soils and those on salt-free soils.

\subsection{Salt Tolerance}

According to their salt tolerance, Chapman (1942) [43] grouped the halophyte under two groups: (i) eu-halophytes, subdivided into the three subgroups meso-halophytes, meso-euhalophytes, en-euhalophytes; (ii) and mio-halophytes.

- Eu-halophytes (extreme halophytes) are plants that can grow in seawater or tolerate more than $200 \mathrm{mM} \mathrm{NaCl}$ (up 5\%), and occur almost exclusively in environments of high salinity [26]. Following the eHALOPH database, this group contains 333 species, members of 70 families of flowering plants. The $75 \%$ of eu-halophytes belong to just 19 families. Eu-halophytes are rather rare amongst flowering plants, representing just $0.4 \%$ of the 350,699 accepted names in 'The Plant List' within $20 \%$ of its 642 families. Some species of Atriplex, Salicornia, Suaeda, and Salsola can be included in this group.

- Mio-halophytes are plants that grow in habitats with low levels of salinity (less than $0.5 \% \mathrm{NaCl})$.

Much later, Grigore and Toma (2010) [44] proposed a new classification of halophytes, distinguishing the extreme halophytes from meso-halophytes, and dividing the extreme halophytes between irreversible and reversible. Thus, based on the analysis of the anatomical features of some taxa and ecological factors, they concluded that succulent Amaranthaceae (e.g., Salicornia europaea, Suaeda maritima, Halimione verrucifera) that grow only in very salinized environments, are irreversible halophytes. Conversely, reversible halophytes 
(e.g., Atriplex sp., Bassia sp., and Camphorosma sp.) are not strictly related to high salinity, and are able to pass from highly salinized areas to less salinized soils.

Based on the different mechanism of salt tolerance, halophytes can be further classified as follows [45]:

- $\quad$ Salt-excluding (root-excluding type) are halophytes (also known as pseudo-halophytes) that protect the shoot from salinity through apoplastic barriers in the roots and interveinal recycling of ions. Mangrove vegetation shows such a type of tolerance.

- $\quad$ Salt-excreting (endo- and eso-recretohalophytes) are plants that avoid cellular damage by releasing excess salts to the outside via specialized structures called salt glandssuch as species of Limonium, Tamarix, Spartina, Avicennia, and Frankenia-or from epidermal bladders on the leaves, such as species of Atriplex and Chenopodium.

- $\quad$ Salt-accumulating are plants able to accumulate salts that are compartmentalized into vacuoles and used for osmotic adjustment, e.g., Salvadora persica, Sesuvium portulacastrum, Suaeda nudiflora.

\subsection{Habitat and Geographical Distribution}

The classification based on the habitat and geographical distribution includes hydrohalophytes and xero-halophytes [46]:

- Hydro-halophytes are halophytic plants that need aquatic conditions or wet soil. Species growing in aquatic environments belong to this group, such as the mangrove forests, tidal marshes or coastal lagoons, and the brackish marshes of the temperate zone. Zannichellia palustris and Althenia filiformis are typical hydro-halophytes in the Mediterranean area $[47,48]$.

- Xero-halophytes grow in environments with dry soil due to high evapotranspiration. Most plants living in desert areas and succulents belong to this group. Atriplex canescens or A. halimus are xero-halophytes that tolerate both salt and drought stress.

\section{Mediterranean Halophytes}

In the Mediterranean regions, Amaranthaceae are the dominant angiosperm family, with halophyte species such as Salicornia sp., Sarcocornia sp., Suaeda sp., Salsola sp. and Atriplex sp. They are followed by Poaceae, such as Hordeum sp., Puccinellia sp., and Sporobolus sp. [25,26]. Halophyte species are mostly found in coastal brackish areas that are subjected to periodic flooding.

The halophytes reported in Table 1 were selected for this review.

The choice took advantage of both their diffusion and importance at an environmental level in the Mediterranean regions, and their degree of salt tolerance recognized by the main international databases such as eHALOPH. The species were then characterized from a botanical point of view and investigated regarding the availability of data on their potential as food-crop sources. Some data have also been provided on the distribution and availability of these species on the Italian territory, with reference to the Tyrrhenian coasts [49,50] (Figure 2a,b). These areas represent an important germplasm reserve for the use of local varieties or ecotypes. The species are reported with the scientific and common name, the type of halophytism, and the edible organs.

For all the species considered, we followed the taxonomic nomenclature reported by Bartolucci et al. (2018) [51], except for Soda inermis, herein kept as Salsola soda. This is due to the taxonomic difficulties of not being fully clarified by the Angiosperm Phylogeny Group classification [52], related to the revisions of the genus Salsola, from which the taxon Soda was separated with the only species Soda inermis. 
Table 1. List of halophytes selected on the basis of their diffusion in the Mediterranean region and their type of halophytism according to eHALOPH [24]

\begin{tabular}{|c|c|c|c|c|}
\hline Botanical Name & Family & $\begin{array}{l}\text { Common Name in English, French, } \\
\text { German and Italian }\end{array}$ & Type of Halophytism & Edible Organs \\
\hline $\begin{array}{l}\text { Atriplex littoralis L. (Syn.: Atriplex patula L. var. } \\
\text { littoralis (L.) A. Gray) }\end{array}$ & Amaranthaceae & $\begin{array}{l}\text { Grassleaf orache, Arroche du littoral, } \\
\text { Strand-meide, Atriplice litorale. }\end{array}$ & Psammophyte & Leaves \\
\hline $\begin{array}{l}\text { Atriplex prostrata Boucher ex DC (Syn.: Atriplex latifolia } \\
\text { Wahlenb. = Atriplex hastata L. var. prostrata (Boucher ex } \\
\text { DC.) Lange) }\end{array}$ & Amaranthaceae & $\begin{array}{l}\text { Hastate orache, Arroche couché, } \\
\text { Spiess-meide, Atriplice prostata }\end{array}$ & $\begin{array}{l}\text { Eu-halophyte } \\
\text { Meso-hydrohalophile }\end{array}$ & Leaves \\
\hline $\begin{array}{l}\text { Beta vulgaris L. subsp. maritima (L.) Arcang. (Tuscany, } \\
\text { Sardinia, Sicily) }\end{array}$ & Amaranthaceae & $\begin{array}{l}\text { Sea beet, Bette maritime, Wilde übe, Bietola } \\
\text { marittima }\end{array}$ & Mio-halophyte & Leaves \\
\hline Cakile maritima Scop. subsp. maritima & Brassicaceae & $\begin{array}{l}\text { Searocket, Roquette de mer, Strandrauke, } \\
\text { Ravastrello di mare }\end{array}$ & $\begin{array}{l}\text { Psammophile } \\
\text { Halo-nitrophilous }\end{array}$ & Leaves \\
\hline $\begin{array}{l}\text { Halimione portulacoides (L.) Aellen (Syn.: } \\
\text { Atriplex portulacoides L.) }\end{array}$ & Amaranthaceae & $\begin{array}{l}\text { Sea pursiane, Arroche faux-pourpier, } \\
\text { Strand-salzmeide, Porcellana di mare }\end{array}$ & $\begin{array}{l}\text { Eu-halophyte } \\
\text { Hydro-halophyte }\end{array}$ & Leaves \\
\hline Portulaca oleracea L. subsp. oleracea & Portulacaceae & $\begin{array}{l}\text { Common pursiane, Purcelane, } \\
\text { Portulach, Porcellana }\end{array}$ & Xero-halophyte & $\begin{array}{l}\text { Leaves } \\
\text { Stem }\end{array}$ \\
\hline $\begin{array}{l}\text { Salicornia perennans Willd. subsp. perennans (Syn.: } \\
\text { Salicornia europaea auct.; Salicornia patula Duval-Jouve). }\end{array}$ & Amaranthaceae & $\begin{array}{l}\text { Grasswort, Salicorne etaleé, Pannonien } \\
\text { glasschmaiz, Salicornia patula }\end{array}$ & $\begin{array}{l}\text { Eu-halophyte } \\
\text { Xero-halophyte }\end{array}$ & Stem \\
\hline $\begin{array}{l}\text { Salicornia perennis Mill. subsp. perennis (Syn.: } \\
\text { Sarcocornia perennis (Mill.) A.J.Scott subsp. perennis). }\end{array}$ & Amaranthaceae & $\begin{array}{l}\text { Perennial grasswort, Salicorne vivace, } \\
\text { Ausdauernde gliedermeide, Salicornia } \\
\text { radicante }\end{array}$ & $\begin{array}{l}\text { Eu-halophyte } \\
\text { Hydro-halophyte }\end{array}$ & Stem \\
\hline Salsola soda L. (Syn: Soda inermis Fourr.) & Amaranthaceae & $\begin{array}{l}\text { Monk's beard, Soude commune, } \\
\text { Soda-salzicraut, Agretto }\end{array}$ & Eu-halophyte & $\begin{array}{l}\text { Leaves } \\
\text { Young stem }\end{array}$ \\
\hline $\begin{array}{l}\text { Suaeda maritima (L.) Dumort. (Syn.: } \\
\text { Chenopodium maritimum L.) }\end{array}$ & Amaranthaceae & $\begin{array}{l}\text { Sea-blite, Soude maritime, Strand-sode, } \\
\text { Sueda marittima }\end{array}$ & $\begin{array}{l}\text { Eu-halophyte } \\
\text { Mesohydro-halophile }\end{array}$ & $\begin{array}{l}\text { Leaves } \\
\text { Young stem }\end{array}$ \\
\hline $\begin{array}{l}\text { Suaeda vera J.F. Gmel (Syn.: Suaeda fruticosa (L.) Forssk. } \\
\text { subsp. vera (J.F. Gmel.) Maire \& Weiller). }\end{array}$ & Amaranthaceae & $\begin{array}{l}\text { Shrubby sea-blite, Soude vraie, Strauchige } \\
\text { sode, Sueda vera }\end{array}$ & $\begin{array}{l}\text { Eu-halophyte } \\
\text { Halo-nitrophilous }\end{array}$ & $\begin{array}{l}\text { Leaves } \\
\text { Young stem }\end{array}$ \\
\hline
\end{tabular}



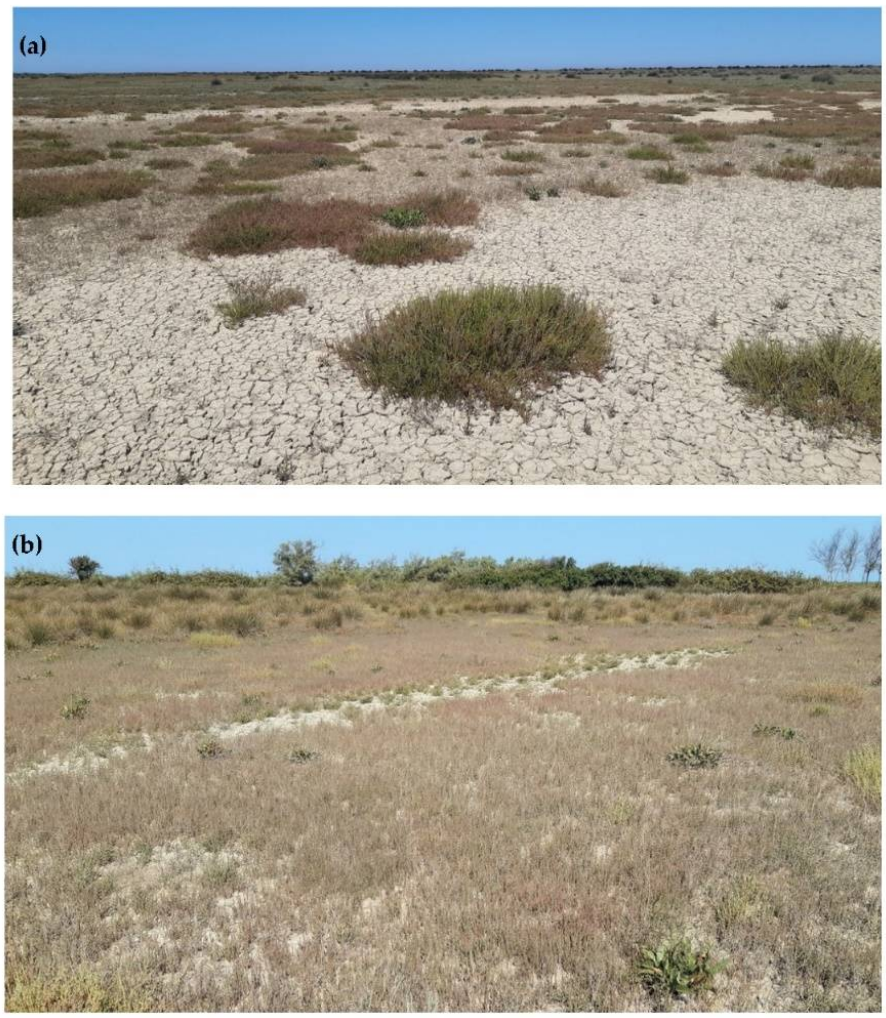

Figure 2. Salt marsh vegetation of Tyrrhenian coasts (Italy): (a) Salicornia perennis communities; (b) Salicornia perennans communities. Photo credit: Andrea Bertacchi.

The species and subspecies Halimione portulacoides, Salicornia perennans subsp. perennans, Salicornia perennis subsp. perennis, Salsola soda, Suaeda maritima and S. vera are exclusive to brackish areas. A. prostrata, B. vulgaris subsp. maritima, and Portulaca oleracea can be found in both brackish areas and internal saline soils. Cakile maritima subsp. maritima, and Atriplex littoralis are halophytes that grow exclusively in dune environments.

The main multidisciplinary traits of the 11 selected species are reported in Appendices A-C.

\section{Halophytes as Potential Novel Crops}

The Mediterranean basin is extraordinarily rich in wild, edible halophytes that grow in both coastal and inland salty areas. The use of wild halophytes for food, and for ethnomedicine, is very ancient. Many plant species have been used traditionally as herbs and vegetables, and accounts of their uses can often be found in ethnobotanic literature [53-55]. This suggests a high potential for Mediterranean halophytes to undergo exploitation by the food industry towards the production of new products with functional and healthy properties, such as beverages, salad mix, microencapsulated oils, food additives, antimicrobial agents, etc. Different parts of halophytes can be consumed, such as the leaves, young shoots, seeds, flower buds, roots, and fruits.

Examples of wild, edible halophytes belong to the genera Atriplex, Bassia, Beta, Cakile, Chenopodium, Crithmum, Plantago, Portulaca, Salicornia, Salsola, and Suaeda. Some halophytes have received attention as potential food sources due to their beneficial effects $[7,12,56,57]$.

To overcome salinity, plants adopt various strategies. A common characteristic of salt tolerance is the leaf accumulation of L-proline. It is an amino acid commonly synthesized in the cytosol and stored in the chloroplasts, and its accumulation rises to $80 \%$ of the amino acid pool when plants are exposed to environmental stress [58]. Proline is well known for its osmoprotectant activity, such as its ability to change cell osmotic pressure, so its presence helps halophytes to counteract salty soils. Therefore, proline is considered to play a pivotal role in defense / protective mechanisms, as the scavenging activity against 
reactive oxygen species, to provide stabilization of the cellular membrane and play the role of a metal chelator [58]. Another compound accumulated by halophytes is glycine betaine, which interact with macromolecules (proteins, enzymes) and contribute to the mitigation of salinity stress [59]. Salsola soda (Syn.: Soda inermis) is an example of a glycine betaine accumulator [60].

Some halophytes are also a good source of nutraceuticals. For instance, Salicornia perennis (Syn.: Sarcocornia perennis subsp. perennis) is used in the human diet for its nutraceutical components. S. perennis leaves are rich in proteins $(6.9 \mathrm{mg} / 100 \mathrm{~g} \mathrm{~d} . \mathrm{w}$.$) , polyunsaturated$ fatty acids (PUFA; linolenic acid is about $21 \%$ of PUFA), and minerals such as $\mathrm{Ca}, \mathrm{Mg}$, Fe and K [7]. Salicornia ramosissima is used as gourmet food due to the presence of antioxidants as phenolics compounds, and of $\alpha$ - and $\gamma$-tocopherol [7]. Suaeda maritima (Syn.: Chenopodium maritimum) contains a good amount of $\mathrm{Ca}, \mathrm{Mg}, \mathrm{Fe}, \mathrm{Zn}$, and $\mathrm{Cu}$, which represent up to $10 \%$ of the allowed daily intake (ADI) and are a good source of vitamins such as beta-carotene and lutein, vitamin A, and vitamin C [11]. Phenolic compounds and/or derivatives, such as phenolic acids (e.g., gallic acid), phenylpropanoids (e.g., cinnamic acid, caffeic acid), flavonoids (e.g., quercetin and kaempferol) and lignans, are often present in Suaeda sp., Sarcocornia sp., and other halophytic species. Suaeda vera might be a valuable source of phenolic compounds due to its antioxidant, anti-inflammatory, and anticancer properties [61], as well as bioactive flavonoids, and other beneficial properties. Likewise, the leaves of $S$. vera accumulate sugars, especially galactoarabinans, which have a good antioxidant-activity effect and contribute to cell stability [62].

However, other plants accumulate sugar alcohols (e.g., mannitol, inositol, sorbitol) to maintain cell homeostasis. The leaves of B. vulgaris spp. maritima contain several nutraceutical compounds, such as tocopherols, phenols, ascorbic acids, and some fatty acids, although their consumption could be limited by the presence of malic and oxalic acid [12]. In Cakile maritima, the leaf content of minerals, vitamins, and amino acids, such as proline and glycine, increases in response to salt treatment [57,63]. Portulaca oleracea, also named "Global Panacea" by the World Health Organization, contains 3\% carbohydrates, $2 \%$ protein, as well as various vitamins (especially vitamin A) and all the essential minerals. Its leaves are rich in flavonoids and contain alkaloids, including dopa, dopamine, and noradrenalin. Portulaca is a good source of Omega-3 fatty acids ( $\alpha$-linolenic acid and linoleic acid), contained in the leaves, stems and flowers. The presence of various bioactive compounds confers to Portulaca several pharmacological properties, such as antimicrobial, antioxidant, antiinflammatory, antidiabetic, neuroprotective, antiulcerogenic, and anticancer activity [64]. More information about the biochemical characteristics of the 11 selected species are illustrated in Appendices A-C.

\section{Cultivation of Halophytes in Hydroponic Greenhouse}

As potential new vegetable species, halophytes are also candidates for greenhouse cultivation, which can allow year-round production of high-quality products with an efficient use of resources such as water, fertilizers, and manual labor. In the last three decades, protected horticulture has developed in many regions, particularly in the Mediterranean countries (e.g., Spain, Italy, Turkey, and Morocco), where the mild climate during winter makes it possible to produce many crops in simple structures [65]. The increasing competition arising from the globalization of production and marketing, the greater awareness of the environmental impacts provoked by intensive cropping systems, the increasing demand for healthy foods, and the shortage of resources such as water, are forcing greenhouse growers to apply more sustainable growing techniques. The use of greenhouses with better climate control and more advanced growing technologies, such as drip fertigation, hydroponics (or soil-less culture), and integrated control over pests and diseases, are the most relevant aspects of the development of the greenhouse industry worldwide.

Many soilless growing systems have been designed and tested for greenhouse crop production. Nowadays, the term "hydroponics" includes all methods and techniques for cultivating plants without soil in artificial substrates (aggregate culture) or in an aerated 
nutrient solution (liquid or water culture) [66]. Aggregate culture is generally used for row crops with low crop density and long growing cycles, such as Solanaceae, Cucurbits, and strawberry, while water culture is adopted for short-cycle and high-density crops such as leafy vegetables and herbs [66].

We searched SCOPUS for documents on the hydroponic cultivation of halophytic species using the following search strategy (last access: 15 February 2022): TITLE-ABS-KEY (halophyte* OR halophytic*) AND (hydroponic* OR aquaponic* OR aquaculture OR soilless). We found 260 research articles published between 1983 and the beginning of 2022; almost half of these have been published since 2017, demonstrating the recent interest of plant scientist in this subject. Much attention has been paid to the utilization of these species in integrated or multitrophic marine aquaponic systems, in which halophytes are cultivated in undiluted or diluted seawater along with aquatic species such as fish, crustaceans and seaweeds [67]. In these systems, halophytes play a fundamental role in the bioremediation of effluents from aquaculture [68].

The halophytes most studied in hydroponics and aquaponics are the following: Salicornia dolichostachya [69], S. perennans [70,71], S. ramosissima [69,72], S. bigelovii [73], Sarcocornia neei $[74,75]$, Halimione portulacoides [9,76,77], and Portulaca oleracea [78-82]. The crop yield observed in some halophytic species grown in soil-less culture is shown in Table 2, along with other information on growing conditions. We are not aware of any studies conducted on the hydroponic production of the other species selected for this review (Table 1). The hydroponic techniques mainly used for halophytes are deep culture, floating system, and sand culture. Singh et al. (2014) [69] found that in Salicornia dolichostachya and S. ramosissima, the harvestable biomass was greater in hydroponic culture than in sand culture.

One of the main advantages of a hydroponic system over soil cultivation is that plant growth rate, and then crop yield, are increased as result of better mineral nutrition and water uptake. In Israel, under field conditions, Salicornia persica produced 13.4 to $16.0 \mathrm{~kg} / \mathrm{m}^{2}$ of fresh biomass in six months when grown under field conditions on sand dune soil and drip-irrigated with moderate salinity $(10 \mathrm{dS} / \mathrm{m})$, or $18.6 \mathrm{~kg} / \mathrm{m}^{2}$ when grown in an unheated greenhouse on coconut fiber-filled sleeves irrigated with moderately saline aquaculture effluent (EC $4 \mathrm{dS} / \mathrm{m}$ ) [83]. In Salicornia europaea cultivated for two months in a floating system in the typical greenhouse climate conditions of summer in Central Italy and using groundwater or diluted seawater (with salinities ranging between 10 and $30 \mathrm{~g} / \mathrm{L}$ ), the production of fresh shoots was between 7.10 and $9.78 \mathrm{~kg} / \mathrm{m}^{2}$, depending on the salinity of the nutrient solution [70].

Small dimensions and fast growth rate make some halophytes good candidates for the hydroponic production of fresh-cut baby leaves, which are increasingly used for mixed salads. Baby leaves are young plants harvested two to four weeks after seed germination. In addition, hydroponic culture allows the improvement of product quality by appropriate management of the nutrient solution [84]. Tender and very clean leaves and shoots are generally harvested in hydroponic systems, and this facilitates the washing operation with minimal processing. There is a growing interest in the fresh-cut baby leaves of halophytes [15], and some studies have demonstrated the good adaptation of purslane $[85,86]$ and sea fennel [14].

Among soilless growing methods, the floating system is the simplest and most costeffective technique to produce baby leaves at high crop density [86].

Intensive cropping systems, such as greenhouse hydroponics, enhance crop productivity but could affect the produce quality of wild edible plants, particularly as regards their nutritional, nutraceutical and organoleptic traits [87]. Recently, in a study conducted with three species of halophytes (Mesembryanthemum nodiflorum, Suaeda maritima and Sarcocornia fruticosa), harvested from the wild in two different locations in Portugal or cultivated hydroponically, it was found that cultivated plants are more succulent, and have fewer fibers and antioxidants than wild plants [11]. Increased succulence is a positive trait from an organoleptic point of view. 
Table 2. Fresh biomass production of some halophytic species grown in hydroponics under different growing conditions, and at different plant density and salinity levels of the nutrient solution.

\begin{tabular}{|c|c|c|c|c|c|c|c|c|c|}
\hline Species & $\begin{array}{l}\text { Location } \\
\text { (Country) }\end{array}$ & Growing Technique & $\begin{array}{l}\text { Growing Season } \\
\text { and Environment }\end{array}$ & $\begin{array}{l}\text { Growing Cycle } \\
\text { (Days/Month) }\end{array}$ & $\begin{array}{l}\text { Plant Density } \\
\left(\text { Plants } / \mathrm{m}^{2}\right)\end{array}$ & Salinity Level & $\begin{array}{l}\text { Fresh Biomass } \\
\left(\mathrm{kg} / \mathrm{m}^{2}\right)\end{array}$ & Note & Reference \\
\hline $\begin{array}{l}\text { Halimione } \\
\text { portulacoides }\end{array}$ & Portugal & $\begin{array}{l}\text { Hydroponics } \\
\text { (floating system) }\end{array}$ & Growth chamber & 10 weeks & $110-220$ & $20 \mathrm{~g} / \mathrm{L} \mathrm{NaCl}$ & $3.1-5.4$ & & [9] \\
\hline Portulaca oleracea & Jordan & Soil-less substrate & $\begin{array}{l}\text { Unheated } \\
\text { greenhouse, } \\
\text { March-July }\end{array}$ & 5 months & & $5.5-6.5 \mathrm{dS} / \mathrm{m}$ & $14.6-26.9$ & $\begin{array}{l}\text { Total yield depended } \\
\text { on genotypes }\end{array}$ & {$[80]$} \\
\hline Portulaca oleracea & Spain & Microgreens & Growth chamber & 4 weeks & & $0-80 \mathrm{mM} \mathrm{NaCl}$ & $1.51-1.97$ & $\begin{array}{l}\text { Yield was greater at } \\
\text { higher salinity }\end{array}$ & {$[81]$} \\
\hline Portulaca oleracea & Canada & $\begin{array}{l}\text { Hydroponics } \\
\text { (floating system) }\end{array}$ & $\begin{array}{l}\text { Controlled-climate } \\
\text { greenhouse }\end{array}$ & 26 days & 266 & $0-10 \mathrm{mM} \mathrm{NaCl}$ & $4.90-5.73$ & & [79] \\
\hline Portulaca oleracea & Alabama, US & $\begin{array}{l}\text { Mixture of Jiffy mix, } \\
\text { sand, and soil }\end{array}$ & $\begin{array}{l}\text { Controlled-climate } \\
\text { greenhouse }\end{array}$ & 60 days & 20 & $\begin{array}{l}\text { Hoagland nutrient } \\
\text { solution }\end{array}$ & 0.54 & & [82] \\
\hline Salicornia bigelovii & Canada & $\begin{array}{l}\text { Hydroponics } \\
\text { (floating system) }\end{array}$ & $\begin{array}{l}\text { Controlled-climate } \\
\text { greenhouse }\end{array}$ & 28 days & 266 & 6-200 mM NaCl & $0.33-1.69$ & $\begin{array}{l}\text { The greatest yield was } \\
\text { found at } 200 \mathrm{mM} \mathrm{NaCl}\end{array}$ & [73] \\
\hline $\begin{array}{l}\text { Salicornia } \\
\text { dolichostachya }\end{array}$ & Germany & $\begin{array}{l}\text { Sand culture or } \\
\text { hydroponics (floating } \\
\text { system) }\end{array}$ & $\begin{array}{l}\text { Controlled-climate } \\
\text { greenhouse }\end{array}$ & 42 days & 37 & $257-513 \mathrm{mM} \mathrm{NaCl}$ & $0.86-1.06$ & $\begin{array}{l}\text { Yield was greater in } \\
\text { floating system than in } \\
\text { sand }\end{array}$ & {$[75]$} \\
\hline Salicornia europaea & Italy & $\begin{array}{l}\text { Hydroponics } \\
\text { (floating system) }\end{array}$ & $\begin{array}{l}\text { Greenhouse, } \\
\text { summer }\end{array}$ & 58 days & 60 & $\begin{array}{l}0-30 \mathrm{~g} / \mathrm{L} \text { (artificial } \\
\text { sea salt) }\end{array}$ & $4.80-9.84$ & $\begin{array}{l}\text { The lowest yield and } \\
\text { the highest yield were } \\
\text { found at salinity of } 30 \\
\text { and } 10 \mathrm{~g} / \mathrm{L}\end{array}$ & {$[70]$} \\
\hline $\begin{array}{l}\text { Salicornia } \\
\text { ramosissima }\end{array}$ & Germany & Sand culture & $\begin{array}{l}\text { Hydroponics } \\
\text { (floating system) }\end{array}$ & 5 weeks & - & $257-513 \mathrm{mM} \mathrm{NaCl}$ & 1.06 & & [69] \\
\hline Salicornia persica & Israel & $\begin{array}{l}\text { Coconut-fiber-filled } \\
\text { sleeves }\end{array}$ & $\begin{array}{l}\text { Unheated } \\
\text { greenhouse }\end{array}$ & 5 months & - & $4 \mathrm{dS} / \mathrm{m}$ & 18.6 & & {$[83]$} \\
\hline Suaeda glauca & Canada & $\begin{array}{l}\text { Hydroponics } \\
\text { (floating system) }\end{array}$ & $\begin{array}{l}\text { Controlled-climate } \\
\text { greenhouse }\end{array}$ & 27 days & 266 & 6-200 mM NaCl & $4.02-5.65$ & $\begin{array}{l}\text { The lowest yield was } \\
\text { found at } 200 \mathrm{mM} \mathrm{NaCl}\end{array}$ & {$[88]$} \\
\hline
\end{tabular}




\section{Health Risks Associated with the Consumption of Cultivated Halophytes}

For the economic development of halophytic crops, the possible presence of healthhazardous substances must be considered for nitrate and oxalate-which generally accumulate, to a large extent, in species belonging to the Amaranthaceae [89,90]—and $\mathrm{Na}$, with regard to irrigation with saline water. The risk associated with the presence of heavy metals and other environmental pollutants is not considered in this review, as this risk is minimized if halophytes are grown under controlled conditions with safe irrigation water; this is in contrast with the harvest of these plants in the wild, which is prohibited in most areas where these species could be collected.

\subsection{Nitrates}

Nitrate $\left(\mathrm{NO}_{3}{ }^{-}\right)$may be harmful to human health as it can be converted to nitrite $\left(\mathrm{NO}_{2}{ }^{-}\right)$causing methaemoglobinaemia or carcinogenic nitrosamines [89]. According to the World Health Organization (WHO) and the European Commission's Scientific Committee on Food (SCF), the ADI for $\mathrm{NO}_{3}{ }^{-}$is $3.7 \mathrm{mg} / \mathrm{kg}$ b.w. (222 mg for an adult weighing $60 \mathrm{~kg}$ ), while the USA Environmental Protection Agency (EPA) has set an ADI of about $7.0 \mathrm{mg} / \mathrm{kg}$ b.w. The main sources of $\mathrm{NO}_{3}{ }^{-}$in human diet are drinking water, cured meat and vegetables; the latter generally provide $30 \%$ to $94 \%$ of the daily dietary intake of $\mathrm{NO}_{3}{ }^{-}$[89].

The European Commission has established maximum limits for the $\mathrm{NO}_{3}{ }^{-}$content in some vegetable species marketed for fresh consumption or as frozen products: $3000 \mathrm{mg} / \mathrm{kg}$ f.w. for spinach (Spinacea oleracea); $2000-5000 \mathrm{mg} / \mathrm{kg}$ f.w. for lettuce (Lactuca sativa); and $6000-7000 \mathrm{mg} / \mathrm{kg}$ f.w. for rocket salad (Eruca sativa, Diplotaxis sp., Brassica tenuifolia, Sisymbrium tenuifolium). The limits depend on growing conditions. For instance, the limits are higher for vegetables grown in the fall-winter season and under cover, compared to those grown in spring-summer and in an open field. Limits to $\mathrm{NO}_{3}{ }^{-}$levels have been set in other European countries for other species [89]. We are not aware of the maximum $\mathrm{NO}_{3}{ }^{-}$levels set for the halophytes selected for this review.

Many leafy vegetables easily accumulate $\mathrm{NO}_{3}{ }^{-}$in their edible tissues under growing conditions that enhance $\mathrm{NO}_{3}{ }^{-}$uptake by the roots (e.g., high $\mathrm{NO}_{3}{ }^{-}$concentration in the growing medium) while $\mathrm{NO}_{3}{ }^{-}$reduction is hampered. For instance, low solar radiation limits leaf photosynthesis and the availability of reducing equivalents (ferredoxin and $\mathrm{NADPH}$ ) for $\mathrm{NO}_{3}{ }^{-}$reduction, and this account for large $\mathrm{NO}_{3}{ }^{-}$accumulation in plants grown in winter with abundant nitrogen fertilization. Hydroponic cultivation stimulates root mineral uptake and can enhance more $\mathrm{NO}_{3}{ }^{-}$accumulation in leaf tissues compared to soil cultivation [91]. On the other hand, plant mineral nutrition can be controlled by the adjustment of the nutrient-solution composition. For instance, nutrient-solution deprivation [92], or the replacement of $\mathrm{NO}_{3}{ }^{-}$with $\mathrm{Cl}^{-}$[93], during the last few days of cultivation can reduce leaf $\mathrm{NO}_{3}{ }^{-}$content to below the limits set by EU Regulation 2008 [94]. Nitrate accumulation is hampered when plants are grown with high $\mathrm{NaCl}$ in the growing medium due to the competitive interaction between $\mathrm{NO}_{3}{ }^{-}$and $\mathrm{Cl}^{-}$[95]. In the halophyte Suaeda salsa (L.), $\mathrm{NO}_{3}{ }^{-}$reduction and assimilation were stimulated by $\mathrm{Cl}^{-}$application, with a consequent reduction in leaf nitrogen accumulation [94]. Nitrate content can vary very much within species and cultivars, and the degree of $\mathrm{NO}_{3}{ }^{-}$accumulation is associated with the location of nitrate reductase activity and the plant's capacity of $\mathrm{NO}_{3}{ }^{-}$accumulation on halophytes marketed for human consumption. Recently, Labiad et al. (2021) [14] reported that $\mathrm{NaCl}$ concentration and leaf spray with methyl jasmonate did not affect the $\mathrm{NO}_{3}{ }^{-}$ concentration of baby leaves of hydroponically grown Crithmum maritimum, which ranged between 229 and $296 \mathrm{mg} / \mathrm{kg}$ f.w. It was calculated that a daily consumption of $100 \mathrm{~g}$ of C. maritimum leaves did not reach the $\mathrm{ADI}$ of $\mathrm{NO}_{3}{ }^{-}$for adult persons. However, the content of $\mathrm{NO}_{2}{ }^{-}$was between 453 and $970 \mathrm{mg} / \mathrm{kg}$ f.w., and the same daily intake of baby leaves largely surpassed the ADI for nitrite ( $3.6 \mathrm{mg}$, according to SCF) [89].

In a greenhouse experiment with Salicornia europaea, grown in summer in an aerated water culture with different concentrations $(0,10,20$ and $30 \mathrm{~g} / \mathrm{L})$ of a synthetic sea salt 
(Instant Ocean ${ }^{\mathrm{TM}}$ ), shoot $\mathrm{NO}_{3}{ }^{-}$content averaged $3397 \mathrm{mg} / \mathrm{kg}$ f.w. in the controls and was much lower in salt-treated plants, with no major differences across salinity levels (the mean value was $1374 \mathrm{mg} / \mathrm{kg}$ f.w.) [70].

\subsection{Sodium}

Sodium is one of the most abundant elements on earth and in seawater, and along with $\mathrm{Cl}^{-}$, is by far the dominant ion in saline soils [96]. Halophytes tolerate a high concentration of $\mathrm{Na}$ in the root zone, and some of them require $\mathrm{NaCl}$ for optimal growth and development [97]. Although root control of Na uptake and the excretion of $\mathrm{Na}$ salts via specific organs (such as salt glands) are among the mechanisms of salt tolerance in some halophytes, most of them are eu-halophytes and accumulate large amounts of $\mathrm{Na}^{+}$and other ions; these are compartmentalized in vacuoles for osmotic adjustment. Therefore, the consumption of halophytes grown in saline conditions originates the risk of excessive intake of Na. According to the World Health Organization [98], the recommended ADI of $\mathrm{Na}$ for adults is $2 \mathrm{~g}$ per day, as greater intake increases the risk of hypertension and cardiovascular diseases.

In wild plants of Beta vulgaris subsp. maritima, Cakile maritima, Portulaca oleracea and Salicornia europaea, harvested in the South-East Spain, the Na content of fresh, edible organs was 171, 308, 42 and $884 \mathrm{mg} / 100 \mathrm{~g}$ f.w., respectively [63]. In Sarcocornia perennis subsp. perennis; S. perennis subsp. alpini; S. ramosissima; and Arthrocnemum macrostachyum, collected in the South of Portugal, edible tips contained, respectively, 2049, 1029, 910 and $1393 \mathrm{mg}$ $\mathrm{Na} / 100 \mathrm{~g}$ f.w. [7]. When Halimione portulacoides was grown hydroponically in artificial seawater $(20 \mathrm{~g} / \mathrm{kg})$ under non-limited nutrient conditions, at harvest, fresh leaves contained $750 \mathrm{mg} \mathrm{Na} / 100 \mathrm{~g}$ f.w. [9]. In the aforementioned study performed by Boni (2020) [70] with hydroponically grown Salicornia europaea, the shoot Na content was 471, 1299, 1672 and $1806 \mathrm{mg} / 100 \mathrm{~g}$ f.w. at salinity level of $0,10,20$ and $30 \mathrm{~g} / \mathrm{L}$, respectively. Therefore, when halophytes harvested in the wild or cultivated with high sodium concentration in the growing medium are consumed, much attention must be paid not to exceeding the ADI recommended by the WHO. On the other hand, dried halophytes such as Salicornia spp. and Halimione portulacoides can replace Na salts to produce low-Na foods [99,100].

\subsection{Oxalate}

Oxalate is an anti-nutritional factor contained in many foods, although those rich in oxalate, such as some vegetables, generally play a minor role in human diet [101]. Oxalate can bind to several minerals, thus reducing their bioavailability in humans. Oxalate can reduce the availability of $\mathrm{Ca}$ due to the formation of an insoluble complex that is contained in the most urinary stones of kidney. Almost all the species considered in this review (Table 1) belong to Amaranthaceae, which includes some vegetables naturally rich in oxalates such as spinach, Swiss chard, and mangold [102]. A general guideline from the American Dietetic Association is to restrict the daily intake of oxalate to $40-50 \mathrm{mg} /$ day [103]. Among the species considered for human consumption, undoubtedly, the most investigated halophyte is purslane, as it is a good source of omega- 3 fatty acids, amino acids, and vitamins. However, this species also contains high concentrations of antinutritional factors, such as $\mathrm{NO}_{3}{ }^{-}$and oxalate [104]. The oxalate content found in hydroponically cultivated purslane ranges from $800 \mathrm{mg} / \mathrm{kg}$ f.w. [105] to more than $6000 \mathrm{mg} / \mathrm{kg}$ f.w. [106], and it has been known to reach $7700 \mathrm{mg} / \mathrm{kg}$ f.w. in plants collected in the wild [107]. With such high contents, a few grams would be enough to exceed the maximum recommended daily intake of oxalates. In purslane, the oxalate content depends on the genotypes [106,108], nitrogen nutrition [105,109], and harvesting stage [110]. Decreasing the nitrogen supply and the $\mathrm{NO}_{3} / \mathrm{NH}_{4}$ ratio in the culture solution has been known to reduce the oxalate content of stems and/or leaves of purslane grown in hydroponics [105,106,110]. Carvalho et al. (2009) [108] found a reduction in the oxalate content of purslane leaves when $\mathrm{NaCl}$ was added to the hydroponic solution. In a recent work with purslane microgreens, cultivated in a growth chamber under different light conditions, oxalic content significantly 
decreased when plants were illuminated with red and blue, or red, blue, and far-red LEDs. The nutrient solution contained $80 \mathrm{mM} \mathrm{NaCl}$, compared with the controls grown under fluorescent light with a $\mathrm{NaCl}$-free nutrient solution [81].

\subsection{Mycotoxigenic Fungi and Mycotoxins in Edible Halophytes: A Potential Health Risk?}

The parts of the halophyte plants used for nutrition could become potential natural sources of mycotoxins, if contaminated by mycotoxigenic fungal species.

Mycotoxins are a series of secondary metabolites produced by a variety of filamentous fungi that can grow on a diversity of crops and are associated with important morbidity and mortality in humans and animals, as well as with major economic losses. Exposure to mycotoxins can occur by inhalation, dermal contact, and primarily by ingestion. Because of their low molecular weight, thermostability and wide spectrum of toxicity, the management of the contamination of food and feed with mycotoxins is problematic [111]. Moreover, it is important to note that climate change is expected to significantly increase mycotoxin production by fungi [112].

A very large number of mycotoxins ( $>300)$ has been identified in agricultural products; correspondingly, mycotoxigenic species can be found in all major taxonomic groups, but the most important are produced by many species of the genera Aspergillus, Penicillium, Alternaria, and Fusarium [113]. Of the great number of known mycotoxins, only a few are commonly found in fruits and vegetables: aflatoxins (produced by several Aspergillus species); ochratoxin A; patulin and citrinin (by Penicillium and Aspergillus species); alternariol and derivatives (by Alternaria species); and trichothecin (by Trichothecium roseum) [114,115].

Mycotoxins rarely cause outbreaks via fresh food, but they are still a risk factor for foodstuffs of plant origin [116]. The contamination of fruits and vegetables with fungi that produce mycotoxins can occur in the field, at harvest and during transportation, and in storage. The presence of fungi on fresh products does not always lead to mycotoxin contamination but reveals that there is a potential risk, because many environmental factors can trigger the formation of mycotoxins [114]. Mycotoxins produced on fresh products may be found in their host tissues even after the fungal mycelium has been eliminated. This is critical for the safety of consumers, since apparently healthy parts can be used as ready-to-eat fresh products or dried food preparations $[117,118]$. In this regard, careful attention should be paid to the composition of the mycoflora on the edible parts, and to the presence of mycotoxigenic fungi.

Many scientific papers report the presence of endophytic fungal populations inhabiting several species of halophytes. Endophytic fungi generally reside within plants without causing any disease symptoms and have gained the attention of many researchers for their ability to produce bioactive metabolites [119-121]. However, recent findings highlight the possible contribution of endophytic strains in differentiating new lineages with an uneven mycotoxin assortment during the exploration of new ecological contexts [122]. Thirumalai et al. (2020) [123] pointed out the importance of investigating the endophyte community of leafy vegetables, especially those with a longer shelf life, for their mycotoxin production.

Therefore, against this background, the data relating to the endophytic, and/or mycotoxigenic fungal species reported on the halophytes described, have been presented in Appendices A-C. The examples confirm that representative fungal genera containing mycotoxigenic species have been frequently reported on halophytes. Therefore, symptomless infections could cause serious food-safety problems, as the plant can look normal, but it may contain mycotoxins.

Many mycotoxin-producing fungal species belonging to the Aspergillus and Penicillium genera have been isolated from low-water-activity environments (aw below 0.8 ) due to their adaptive xerotolerance/halotolerance [124,125]. Maciá-Vicente et al. (2008) [126] found a high occurrence of Aspergillus fumigatus and members of Pleosporales, such as Alternaria species, in saline environments. Recently, Calabon et al., 2021 [127] reviewed the fungal biodiversity in salt-marsh ecosystems. They found 486 taxa associated with different 
hosts, of which $95.27 \%$ (463) belonged to the phylum Ascomycota, and the Pleosporales was the largest order with 178 taxa recorded. Moreover, Pleosporales and Alternaria spp. are known to produce heavily pigmented spores and/or mycelia (especially melanin) that may protect the fungi in a high-salinity environment (UV radiation, desiccation, and extreme temperatures) [128].

Interestingly, within the Pleosporales order, some fungal genera have a host and habitat preference and can be found in marine or saline habitats in association with various kinds of halophytes. The majority of the Neocamarosporium species described so far were found in association with Atriplex hastata, A. prostrata, Beta vulgaris, Halimione portulacoides, Salicornia spp., and Salsola sp.; halotolerance seems to be a typical characteristic of this fungal genus $[129,130]$. The importance of the problem addressed is confirmed by recent observations of the presence of mycotoxigenic fungi and their mycotoxins in some halophytic plants [131,132].

Although toxicological assessments and guidelines are in place to curb the impact of many contaminants on public health, these safeguards cannot be applied to naturally occurring mycotoxins. For this reason, the health risk posed to the consumer by natural mycotoxins appears more serious than the health risk posed by man-made pesticides, preservatives, and other food additives [133,134].

\subsection{Pathogenic Bacteria Potentially Associated with Edible Halophytes}

To the best of our knowledge, there are no studies on the microbial contamination of halophytes intended for human consumption. Nevertheless, we can assume that the contamination of halophyte-based food preparation due to bacteria follows the general guidelines adopted for other vegetables. Bacteria such as Aeromonas spp., Bacillus cereus, Campylobacter spp., Clostridium botulinum, Escherichia coli, Listeria monocytogenes, Salmonella enterica, Shigella spp., Staphylococcus spp., and Yersinia enterocolitica are generally associated with fresh vegetable produce. Among these, E. coli, L. monocytogenes and S. enterica have been found to be responsible of most fresh-produce outbreaks in the United States [135].

The fresh vegetable market, including halophytes, is expanding due to global changes and to consumer habits being more oriented toward healthier lifestyle choices. On the other hand, the diffusion of foodborne illness is often associated with the intake of readyto-eat preparations. These are consumed without being exposed to processing treatments, and pathogen contamination may be uncontrolled as a result. Listeria monocytogenes and Staphylococcus aureus have been proven to have the ability to survive in different types of salad over a range of temperatures, depending on the type of preparation and storage conditions [136]. In fresh-cut vegetables, the microbiological standard for Salmonella spp. is absence in $25 \mathrm{~g}$ of foods [137]; for Listeria monocytogenes, the standard is absence in $25 \mathrm{~g}$ before the food has left the immediate control of the producer, and $<100 \mathrm{cfu} / \mathrm{g}$ in products that are placed on the market during their shelf life [137]. Studies on the presence of enteric pathogens in fresh-cut vegetables indicate that contamination with pathogens occurs infrequently [138]. However, in a recent study, increased consumption of fresh produce was correlated with increased outbreaks of microbial infection of these products [139].

The presence of halophyte species in food preparation is desirable to contribute to the preservation of biodiversity and improving sustainable practices; the development and application of accurate practices in the preparation and prevention of cross-contamination are essential to preclude the presence of pathogens.

\section{Conclusions and Future Perspectives}

Global climate change and soil degradation due to progressive salinization are now quite evident. In this context, halophytes can be of fundamental importance both for the restoration of salinized lands, and as a commercial alternative to traditional crops.

Some halophytes (e.g., Portulaca oleracea and Salicornia spp.) are cultivated and consumed as a novel source of nutraceutical components, conferring beneficial effects, such 
as proline. Further compounds that are well represented are phenolic compounds and/or derivatives, fatty acids, vitamins (tocopherols and ascorbic acid), and some minerals.

For these purposes, multidisciplinary investigations are crucial, starting with the identification of the species, subspecies and ecotypes, and subsequently characterizing their ecological, nutritional, and organoleptic properties, for their use as crop plants. This approach may not always be simple, as the halophytes, especially some members of the Amaranthaceae, often have high intraspecific morphological and physiological variability.

The cultivation and commercial production of edible halophytes is still in early stages; in the European market, their consumption is recent, and therefore not covered by any food-safety regulations. Despite the promising future for multiple uses of edible halophytes, there is still little knowledge of natural mycotoxin contamination in these plants, and more investigations are required before conclusions can be drawn on the health risks associated with their consumption.

Author Contributions: Conceptualization, A.P., L.P., T.L., A.B., A.T., S.P. and C.S.; writing-original draft, A.P., L.P., T.L., A.B., A.T. and S.P.; review and editing, A.P., L.P., T.L., A.B., A.T., S.P. and C.S.; supervision, A.P.; funding acquisition, C.S. and A.P. All authors have read and agreed to the published version of the manuscript.

Funding: This study was conducted in the framework of the project entitled "HALOphytes grown in saline Water for the production of INnovative ready-to- eat salad-HALOWIN" and funded by the University of Pisa, "PRA 2020”, grant number PRA_2020_43.

Institutional Review Board Statement: Not applicable.

Informed Consent Statement: Not applicable.

Data Availability Statement: Not applicable.

Conflicts of Interest: The authors declare no conflict of interest.

\section{Appendix A}

The systematic, morphological, and biochemical characteristics of the species considered in the present work (Table 1) are reported below. Nomenclature follows the APG IV classification system [52].

AMARANTHACEAE Juss.-Dicotyledons, annual or perennial, shrubs, or herbs. Leaves are simple without stipules, succulent or reduced in some taxa. Small flowers, bisexual or unisexual, in flower heads or spikes. Simple perianth of 3-5 scary tepals. Stamens equal in number to the tepals, and alternated with petaloid staminoids. Fruit is utricle or pyx. Seeds with annular embryo surrounding the mealy albumen. Cosmopolitan.

\section{Appendix A.1. Genus Salicornia L.}

The genus Salicornia includes several annual and perennial plants, divided into a series of diploid and tetraploid species and subspecies [140], difficult to distinguish based on macroscopic characteristics. The genus name derives from the Latin 'sal' (salt) and 'conus' (horn), due to the shape of the branches. These plants have articulated stems, succulent and apparently aphill, with very small flowers (hermaphrodites) that are difficult to observe. These are normally inserted in terminal racemes consisting of triflorous dicases, inserted at the axil of leaf-like bracts, in correspondence with each node. In this Appendix, following updates of Bartolucci et al. (2018) [51], reference is made to subspecies Salicornia perennans Willd. subsp. perennans, and S. perennis Mill. subsp. perennis. Other authors include the latter species in the genus Sarcocornia $[141,142]$. The two species are both diploid $(2 \mathrm{n}=18)$.

Appendix A.1.1. Salicornia perennans Willd. subsp. perennans (Syn.: Salicornia europaea auct.; Salicornia patula Duval-Jouve; Salicornia herbacea (L.).) Eu-halophyte

Botanical traits

Biological form: scapose therophyte. 
Morphological characteristics: Stem 5-40 cm tending to purple with ripening, very branched at the base. The inflorescence is trifloral with the central flower much larger than the lateral ones. Mature seeds covered with curved and often hooked hairs.

Habitat: salt marshes, soils muddy clay-asphyxial, basic and hypersaline. S. perennans is widespread along almost all the Italian coasts. It grows in lagoons and basins subjected to periodic flooding of seawater and at the edges of the salt flats, along the coasts.

Chorological type: W-Europe (Euri-Medit.)

Flowering period: September-November.

S. perennans tolerates a $\mathrm{NaCl}$ concentration of more than $1000 \mathrm{mM}$, although its optimal growth has been observed at $200 \mathrm{mM}$ [143]. The plants contain large amounts of minerals, especially $\mathrm{Ca}, \mathrm{Mg}$ and iodine (I), and osmolytes such as betaine and choline [144].

\section{Biochemical traits}

The plant is cultivated for its oilseed used in human consumption and as a forage crop in saline coastal environments.

Wang et al. (2021) [145] performed metabolomic characterization of the leaves of S. europaea, and discovered 694 metabolites involved in the tolerance to salt conditions: flavonoids, alkaloids and coumarins, and the branched chain amino acids, glucosamine, maltose, and glucose. At a high salt concentration ( $500 \mathrm{mM} \mathrm{NaCl})$, the succulence is due to the $\mathrm{Na}^{+}$content of the cell, which promotes the osmotic adjustment and increases the proline and other osmolyte content, maintaining cell turgor [146]. The first investigation on the effects of salt stress in S. europaea was elucidated in 2009 [147] by looking at the growth parameters, free proline content, ion accumulation, lipid peroxidation, and several antioxidative enzymes activities of in vitro plantlets. At high salt concentration $(300 \mathrm{mM})$, peroxidation of lipid membranes occurs, reflecting free-radical-induced oxidative damage at the cellular level [148], counteracted by the increase in polyphenol content and enzymatic scavenger activity (peroxidase and superoxide dismutase). Salicornia shoots are also a good source of fatty acids such as linoleic and oleic acids [12,54].

The oilseeds of S. herbacea (Syn.: S. perennans) are rich in proteins [149] and linoleic (75.6\%) and oleic acids (13.0\%); they also contain a significant amount of palmitic, linoleic, and stearic acids, as well as tetracosanol, and octacosanol [149]. The composition is very similar to the composition of safflower oil. The extracts exhibit activity against different kinds of oxidative stress, inflammation, diabetes, asthma, hepatitis, cancer, and gastroenteritis [150].

\section{Plant mycobiota}

The analysis of the fungal community structure in Salicornia europaea in Poland revealed the presence of nine orders, and among them, the most representative were Pleosporales (main genus Alternaria) and Eurotiales (including the genera Aspergillus and Penicillium) [151,152].

Pleospora sp., Alternaria alternata, and A. phragmospora were the major endophytes found in Salicornia europaea in Japan [153].

Lopes et al. (2020) [132] investigated the presence of potentially mycotoxigenic fungi and the occurrence of aflatoxins (AFB1, AFB2, AFG1, AFG2) and ochratoxin A in fresh and powdered samples of Salicornia spp. (wild and cultivated) in Portugal. Potentially toxigenic fungi (Aspergillus flavus, A. fumigatus, A. niger, and Penicillium sp.) were present in most of the analyzed samples, and relevant levels of AFB1 $>5 \mu \mathrm{g} \mathrm{kg}{ }^{-1}$ and total aflatoxins (sum of AFB1, AFB2, AFG1 and AFG2) $>10 \mu \mathrm{g} \mathrm{kg}^{-1}$ were found in various samples. Ochratoxin A was not found in any of the samples. It is interesting to note that a sample of Salicornia supplied by a local producer exhibited very high levels of contamination, but no aflatoxins were found in the samples grown either in greenhouses or in hydroponic cultivation. The presence of aflatoxins may not be considered a serious problem for those who consume Salicornia occasionally; however, this halophyte is widely used as forage [154], which, if contaminated, could be a risk to both animals and humans. 
Appendix A.1.2. Salicornia perennis Mill. subsp. perennis (Syn.: Sarcocornia perennis (Mill.) A. J. Scott subsp. perennis). Eu-halophyte

\section{Botanical traits}

Biological form: succulent chamaephyte.

Morphological characteristics: Bushy stem 50-60 cm, rooting at the nodes. The inflorescence is 3-flowered with the central flower a little larger than the lateral ones. Mature seeds covered with short, curved hairs.

Habitat: hypersaline margins of the brackish areas where S. perennans also grows, often dry in summer.

Chorological type: Medit.-Atlant.

Flowering period: September-November.

Biochemical traits

The halophyte S. perennis contains high levels of proteins $(6.9 \mathrm{~g} / 100 \mathrm{~g}$ d.w.) and n-3 polyunsaturated fatty acids (PUFA) - particularly linolenic acid (21.1\% of total FA) - and low concentrations of toxic metals, below the limits imposed by the European Commission. The plant is also a good source of minerals, particularly Na $(64.1 \mathrm{mg} / \mathrm{g} \mathrm{d} . \mathrm{w}$.$) , and$ manganese (31.4 mg/g d.w.). Other detected natural minerals include the presence of $\mathrm{Ca}$, $\mathrm{Mg}$, Fe and $\mathrm{K}$. Leaf extracts show great antioxidant potential due to the content of total phenols (20.5 mg GAE/g d.w.), carotenoids ( $280 \mathrm{mg} / 100 \mathrm{~g}$ d.w.), and tocopherols (vita$\mathrm{min} \mathrm{E}, 1.2 \mathrm{mg} / 100 \mathrm{~g}$ d.w.) [7]. In addition, flavonoids, such as kaempferol and quercetin, and to a lesser extent, gallic acid and other hydroxy-benzoic acids, have been reported in Sarcocornia species; the intake of $100 \mathrm{~g}$ of edible portions (wet weight) of S. perennis would cover $71 \%$ of said recommended daily dose, to reduce the risk of cardiovascular and coronary heart disease [7]. Other metabolites, such as pectic polysaccharides, can protect the immune and reproductive systems of mammals against toxic chemical-inducers of oxidation reactions. All the cited compounds confer important biological properties, such as antioxidant, anti-inflammatory, hypoglycemic and cytotoxic activity [6].

Plant mycobiota

Petrini and Fisher (1986) [155] found 32 species of endophytic fungi in apparently healthy stems from 20 tussocks of Salicornia perennis on a salt marsh at Dawlish Warren, Devon, UK. The most frequent colonizers belonging to the order Pleosporales were Pleospora salicorniae and P. bjorlingii, and two species of Stagonospora. Other isolates were Alternaria alternata, A. tenuissima, Cladosporium tenuissimum, Coniothyrium sp., Hypoxylon bipapillatum, Leptosphaeria sp., Phoma sp., Pleospora herbarum and Septoria sp.

\section{Appendix A.2. Genus Suaeda Forssk ex J.F. Gmelin}

The Suaeda genus includes about 100 species, mainly halophytes with fat leaves; they grow in saline and alkaline wetlands and deserts almost all over the world but are primarily extra-tropical. The species are annuals or perennials, dwarf shrubs or, rarely, trees. The genus is known to be taxonomically very complicated due to its high polymorphism [156].

The two species Suaeda maritima (L.) Dumort., and S. vera J. F. Gmel, described below, are both diploid with $2 n=36$.

Appendix A.2.1. Suaeda maritima (L.) Dumort. (Syn.: Chenopodium maritimum L.;

Schoberia maritima (L.) C.A. Mey). Eu-halophyte/halo-nitrophilous

\section{Botanical traits}

Biological form: scapose therophyte.

Morphological characteristics: A $30-80 \mathrm{~cm}$ plant, first glaucous and then, with ripening, tending to red. Leaves $(8-16 \mathrm{~mm})$ with a semi-circular section, the lower opposite, the others alternate, never pointed. Flowers in glomeruli at the axil of the leaves on the upper branches.

Habitat: Mainly salty coastal areas, both on sandy soils in the back dune and clayey soils, where there is an accumulation of organic remains; it is also ecologically useful in swamp formations due to its ability to trap mud. 
Chorological type: Medit.-Occid.

Flowering period: July-August.

Biochemical traits

Suaeda maritima is a succulent halophyte, suitable for human consumption due to the high concentrations of proteins, fiber and minerals [11]. The leaves have a pleasant, salty taste due to the high salt content [157]. S. maritima contains a noticeable content of various minerals, such as $\mathrm{Ca}, \mathrm{K}, \mathrm{Mg}, \mathrm{Fe}, \mathrm{Zn}$ and $\mathrm{Cu}$, and the consumption of $20 \mathrm{~g}$ of fresh leaves could represent $2-10 \%$ of the recommended daily intake [11,158]). It is also rich in vitamins. Regarding fat-soluble vitamins, $\beta$-carotene represents the most important provitamin A (9.30-20.7 mg/100 g d.w.). The species also has high content of lutein $(20-89 \mathrm{mg} / 100 \mathrm{~g}$ d.w.) in comparison with other vegetables. These metabolites are involved in many physiological processes, such as immune response, and the prevention of vision-degenerative diseases related to age in humans and animals [159]. The content observed in Vitamin A is $5.39 \mathrm{mg} / 100 \mathrm{~g}$ d.w., showing similar values to those of species with good sources of vitamin A (e.g., spinach $5.45 \mathrm{mg} / 100 \mathrm{~g} \mathrm{d.w.)} \mathrm{[11].} \mathrm{S.} \mathrm{maritima} \mathrm{shows}$ a content of ascorbic acid (Vitamin C) above that of other vegetables, such as parsley and broccoli $[11,160]$. In addition, other antioxidant metabolic compounds, such as total phenolic, flavonoids and condensed tannin, are detected in S. maritima [11]. The most representative compounds are chlorogenic acid, cinnamic acid, catechin hydrate, coumaric acid, luteolin-7-O-glucoside. The results of such work confirmed the direct correlation between the content of phenolic compound flavonoids, with the antioxidant activity of the extracts.

The cultivated plants of $S$. maritima showed a different nutritional profile compared with wild plants in [11]: leaves had a higher content of moisture, ash, and fiber. High water content and succulence are the result of a high concentration of osmolyte solutes, such as proline and glycine betaine, that contribute to the regulation of turgor [157].

Plant mycobiota

The genetic diversity of the fungal endophytes isolated from halophytic plants, sampled from salt marshes located in west and South Korea, was studied using the internal transcribed spacer (ITS) region as a DNA barcode for the classification of the specimens. Generic richness and diversity were determined by counting the genera present in the fungal communities in plant samples. In S. maritima sampled in west Korea, 7 genera and 7 species were found, and the most abundant genera were Alternaria and Cladosporium [161]. In South Korea 11 genera and 21 species were isolates from $S$. maritima samples and the most dominant genus was Fusarium, followed by the genera Penicillium and Alternaria [162]. The endophyte assemblage of $S$. maritima in India was dominated by Camarosporium palliatum as indicated by its mean density of colonization [163].

Appendix A.2.2. Suaeda vera J. F. Gmel (Syn.: Suaeda fruticosa (L.) Forssk.; Suaeda fruticosa (L.) Forssk. subsp. vera (J. F. Gmel.) Maire \& Weiller;

Chenopodium fruticosum (L.). Eu-halophyte (Halo-nitrophilous)

Botanical traits

Biological form: nano-phanerophyte.

Morphological characteristics: A plant that can reach one meter in height, with woody, very branchy and glaucous stems with semi-cylindrical and slightly more pointed leaves $(8-15 \mathrm{~mm})$ than S. maritima.

Habitat: salty and nitrophilous soils, but soils of calanchive and internal marly areas.

Chorological type: Cosmopol.

Flowering period: June-July.

Biochemical traits

The obligate halophyte $S$. fruticosa is known to increase its content of sugars, protein, and proline under high salt concentration [164]. Both the leaves and seeds are edible and used for human consumption. Succulence is one of the mechanisms used by this species to protect itself from salt stress [164]. Regarding sugars, the composition seems 
related to that of galactoarabinans, by the presence of pectin-like polysaccharides and neutral monosaccharides (including arabinose, mannose, galactose, rhamnose, glucose, and xylose). These polysaccharides possess significant potential in antioxidant activity effect [62]. Other phytochemicals with antioxidant activity-such as phenols, flavonoids, tannins, proanthocyanidins, and carotenoids-have been isolated from S. fruticosa extracts, reproducing the therapeutic benefits of these plants, and also used as herbal tea [165]. Alkaloids and saponins have also been detected, to enlarge their phytopharmacological use. $S$. fruticosa produces numerous seeds under saline conditions and contains about 25\% oil [12], four saturated fatty acids (11.04\%), and six unsaturated fatty acids (89.06\%) [166]. These nutritional components promote the consumption of the leaves and seeds of $S$. fruticosa as food and feed. Unsaturated fatty acids (linoleic and oleic acids) confer the ability to overcome damage to the cell membrane under stress conditions, by controlling the expression of desaturase genes [167]. This plant is used in folk medicine for its hypoglycemic and hypolipidemic activity [12]; a good anti-inflammatory effect was also detected in polysaccharide extracts [62]. Interesting anticancer activity against human lung carcinoma and colon adenocarcinoma cell lines were reported for dichloromethane extracts [168].

Plant mycobiota

Fisher and Petrini (1987) [169] found that Camarosporium spp. (85.3\% in stems) and Colletotrichum gloeosporioides (30\% in leaves) endophytically colonized S. fruticosa in England.

\section{Appendix A.3. Genus Salsola L.}

Recently, the Salsola genus has been revised with the creation, among others, of the new taxa Soda (which would therefore include $S$. soda species as $S$. inermis). However, the original classification is still maintained in this review, as the new taxonomic classification has not yet been fully clarified in APG IV. The species of Salsola are mostly subshrubs, shrubs, small trees, and rarely, annuals. The leaves are mostly alternate, rarely opposite, simple, and entire. The bisexual flowers have five tepals and five stamens.

\section{Salsola soda L. (Syn.: Soda inermis Fourr.). Mio-halophyte (halo-nitrophilous)}

\section{Botanical traits}

Biological form: scapose therophyte.

Morphological characteristics: $20-120 \mathrm{~cm}$ tall, often red with ripening; leaves $20-40 \mathrm{~mm}$ long, succulent, opposite and slightly sharp; axillary flowers.

Habitat: salty coastal areas on both sandy soils in the back dune and clayey soils, where there is an accumulation of organic remains.

Chorological type: Paleotemp.

Flowering period: July-August.

Biochemical traits

S. soda represents a valid alternative crop for saline soils, because of its accumulation and tolerance to very high levels of $\mathrm{Na}$ [60]. Therefore, S. soda is considered a "bio-desalinating companion plant" for tomatoes and peppers in saline soils in the Mediterranean area [60]. Its cultivation can be achieved in different saline $(\mathrm{NaCl})$ concentrations and in desalinized soils [170]. S. soda (Syn.: S. inermis) is also considered a glycine-betaine accumulator. Various Salsola species, including the species $S$. soda, have been examined for their phytochemical composition, showing the presence of alkaloids, flavonoids, saponins, coumarins, and sterols [171-173]. The shoots contain flavonoid glycosides and triterpenoid saponins [174]. In particular, the presence of quercetin 3-O- $\beta$-D-glucuronopyranoside may confer functional nutraceutical and medicinal properties. In fact, shoot extracts have been found to exhibit hypoglycemic, antioxidant, anti-cholinesterase, and antimicrobial activity [172,175]. Alkaloids present in the extracts from Salsola species have been evaluated against Alzheimer's disease [172]. 


\section{Appendix A.4. Genus Atriplex L.}

The genus Atriplex, with about 300 species, is the richest in species of the Amaranthaceae family. It has worldwide distribution, occurring on all the continents except Antarctica. Annual or perennial herbs or shrubs. The inflorescences consist of axillary or terminal spikes or spicate panicles, or axillary clusters of glomerular flowers. The flowers are unisexual. Some species are monoecious, others dioecious.

Appendix A.4.1. Atriplex littoralis L. (Syn.: Atriplex patula L. var. littoralis (L.) A. Gray). Halo-nitrophilous

\section{Botanical traits}

Biological form: scapose therophyte.

Morphological characteristics: both $40-120 \mathrm{~cm}$ high, with erect angular stem and lanceolate linear leaf lamina.

Habitat: seacoasts, ruderal and sub-saline habitat.

Chorological type: Europe and Paleotemp.

Flowering period: July-October.

Atriplex littoralis germination and growth are reduced at salinities higher than 1\% $\mathrm{NaCl}$ [176]. The plant accumulates salt in the seeds and bracteoles ( 40-50\%) [177]. In adult plants, the salt is accumulated in the aerial parts, like other halophytes in the Amaranthaceae.

\section{Biochemical traits}

Regarding the 300 species belonging to the Atriplex genus, the species A. littoralis has not been deeply investigated for phytochemical content and biological activity. The plant is rich in flavonoids, glycosides, alkaloids, amino acids, minerals, saponins, and phytoecdysteroids [178].

Plant mycobiota

Some Alternaria species (A. alternata, A. raphani, A. tenuissima), Cladosporium oxysporum, Fusarium moniliforme and F. tricinctum were found in Atriplex littoralis sampled at various growth stages from an inland salt marsh in Canada $[178,179]$.

Appendix A.4.2. Atriplex prostrata Boucher ex DC (Syn.: Atriplex hastata L. var. prostrata (Boucher ex DC.) Lange; Atriplex latifolia Wahlenb.). Halo-nitrophilous

Botanical traits

Biological form: scapose therophyte.

Morphological characteristics: both $40-120 \mathrm{~cm}$ high, with erect angular stem and hastate/triangular leaf lamina.

Habitat: seacoasts, ruderal, and sub-saline habitat.

Chorological type: Europe and Paleotemp.

Flowering period: July-October.

Biochemical traits

Atriplex prostrata is a facultative halophyte. Seed germination has been known to decrease by $25 \%$ at $200 \mathrm{mM} \mathrm{NaCl}$ [179]. In saline environments, $\mathrm{Na}$ accumulation is associated with a decrease in the content of $\mathrm{K}, \mathrm{Ca}$ and $\mathrm{Mg}$, and with reduced plant growth and photosynthesis [180]. However, some antioxidant enzymes have been known to increase in the aerial organs while the lignin content decreases [181]. Polyphenol content has been shown to increase with external salt concentration [182], but different behaviour of polyamines and ethylene was observed: spermine, putrescine and spermidine content decreased under saline conditions, while ethylene increased together with proline [183].

\section{Appendix A.5. Genus Halimione Aellen}

Monoecious annual or perennial herbs with silvery grey stems and leaves. The leaves are opposite in the lower part and alternate in the upper part of the plants. The leaf blade is oblong with entire margins 
Halimione portulacoides (L.) Aellen (Syn.: Atriplex portulacoides L.). Eu-halophyte

Botanical traits

Biological form: chamaephyte.

Morphological characteristics: species up to $80 \mathrm{~cm}$ tall has a prostrate stem, often rooting at the nodes; opposite leaves with lanceolate lamina, up to $60 \mathrm{~mm}$ long, with obtuse apex.

Habitat: salty and clayey coastal areas.

Chorological type: Circumbor.

Flowering period: June-July.

Biochemical traits

H. portulacoides is an obligate halophyte with succulent leaves. The optimal growing condition was assessed at $200 \mathrm{mM} \mathrm{NaCl}$; however, this species can tolerate up to $1 \mathrm{M}$ $\mathrm{NaCl}$ [184]. Anthocyanins, polyphenols, and proline increases significantly with salinity, being maximal at $1000 \mathrm{mM} \mathrm{NaCl}$ [185]. The activity of superoxide dismutase (EC 1.15.1.1, $\mathrm{SOD})$, ascorbate peroxidase (EC 1.11.1.11, APX), and glutathione reductase (EC 1.6.4.2, GR) is significantly stimulated by salinity in the leaves of $\mathrm{H}$. portulacoides, whereas catalase (EC 1.11.1.6, CAT) activity is maximal in the $0-400 \mathrm{mM} \mathrm{NaCl}$ range. Leaves contain phenolic compounds, mostly sulphated flavonoids that confer high antioxidant activity [184].

The salt tolerance of $H$. portulacoides can be attributed to the leaf waxes containing long chain chloroalkanes. Recently, the polar lipid profile of leaves has been determined and classified in over five classes of phospholipids, three classes of glycolipids characterized by the presence of PUFA (n-3 and n-6 FA), and one class of glycosphingolipids [186].

High productivity and a capacity to grow in soil contaminated by heavy metals also make this species potentially useful for saline soil reclamation and phytoremediation purposes, and even as fodder plants [187]. Volatile organic compounds have been detected in the root exudates [168].

Plant mycobiota

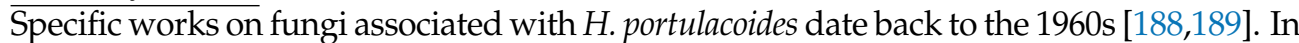
these studies, different fungi were identified. Mycoflora of leaves of $H$. portulacoides growing in two salt marshes showed a high presence of Alternaria tenuis and other Pleosporales, together with Cladosporium herbarum. More recently, these finding were confirmed by molecular studies (BOX-PCR fingerprinting, and sequencing of the ITS region of the ribosomal DNA cluster) performed on 111 isolates obtained from the roots, stems, and leaves of H. portulacoides; this revealed that $74.5 \%$ belonged to the order Pleosporales [190]

\section{Appendix A.6. Genus Beta L.}

This genus consists of annual, biennial, or perennial species. The stems, erect or procumbent, have alternate leaves, ovate-cordate to rhombic-cuneate; the margins are mostly entire, with obtuse apex. The inflorescences are long spike-like cymes or glomerules, and flowers are bisexual.

Beta vulgaris L. subsp. Maritima (L.) Arcang. (Syn.: Beta maritima L.) Mio-halophyte

Botanical traits

Biological form: hemicryptophyte (rarely therophyte).

Morphological characteristics: $20-80 \mathrm{~cm}$ tall, with many erect angular stems; flowers in leafy ears; spatulate leaves up to $220 \mathrm{~mm}$ long and with reddened petiole.

Habitat: pebbly coastal soils.

Chorological type: Euri-Medit (Atl.).

Flowering period: June-August.

Biochemical traits

The leaves of Beta vulgaris subsp. Maritima constitute a healthy food against digestive disorders, burns, throat pains and anaemia [191]. Shoots' fresh weight is increased with salinity [192]. Under salt stress, sea beet roots revealed a higher content of $\mathrm{Cl}^{-}$and $\mathrm{Na}^{+}$, 
and a lower content of $\mathrm{K}^{+}$[192]. Mg content is increased in shoots and roots, while Ca is less affected by salinity.

In a comparative study with other halophytes, B. vulgaris subsp. Maritima showed an appreciable content of malic acid (51.36 mg/100 g d.w.) and oxalic acid (581 mg/100 g d.w.) [191]. The four chemical structures of tocopherols were detected, but $\alpha$-tocopherol (vitamin E activity) was the major component. Total phenols (62 mg/100 g d.w.), total flavonoids (21.6 mg/100 g d.w.), and vitamin C (20 mg/100 g d.w.) were also present in the leaf extracts, and the antioxidant activity was significantly correlated with the antioxidant compounds [191]. The basal leaves contain fatty acids, such as $\alpha$-linolenic acid, linoleic acid, and palmitic acid. The aerial parts contain essential oil rich in sesquiterpenes (69.5\%) with a prevalence of $\gamma$-irone (26.3\%) [193]. They showed antioxidant, cytotoxic, anticholinesterase and anti-tyrosinase activity.

\section{Appendix B}

BRASSICACEAE Burnett-Dicotyledons, herbaceous, annual, and perennial, and shrubs. Leaves without stipules, flowers arranged in racemes, panicles, or corymbus heads or spikes. Each flower has four petals, set alternating with the sepals, and six stamens. Fruit is silique or silicle. Cosmopolitan.

\section{Appendix B.1. Genus Cakile Mill.}

Annual plants with an erect or decumbent stem. The common species in Europe and North America grow close to the coast, often in dunes. Their leaves are fleshy. Flowers are typically pale mauve to white, with petals about $1 \mathrm{~cm}$ in length. Each fruit has two sections, one that remains attached to the adult, and another that falls off for dispersal by wind or water.

\section{Cakile maritima Scop. subsp. maritima. Halo-nitrophyle (Psammophile)}

\section{Botanical traits}

Biological form: scapose therophyte.

Morphological characteristics: Stem 10-30 cm tall, often devoid of leaves. Odd-pinnate divided leaves (max $50 \mathrm{~mm}$ long); small lilac flowers; siliqua (10-20 mm) formed by two superimposed articles, the lower more or less rhombic, the upper conical.

Habitat: sandy coasts, in the dune belt of drift lines.

Chorological type: Medit.-Atl.

Flowering period: January-December.

Biochemical traits

Cakile maritima (Sea Rocket) is a facultative halophyte that tolerates high salt concentration.

Under salinity conditions, fatty acid contents have been detected in the leaves, with $\omega$ 6 PUFAs as the major fatty acid group (17.88\%) [168]. Amino acids-such as GABA, proline and glycine-and sugar content increased, while the phenolic content decreased, in plants subjected to high salt concentration [194]. Other metabolites, such as flavonoids, flavonoid glycosides, sinapic and chlorogenic acid derivatives, are not affected by salinity [57].

Cakile maritima has a high antioxidant capacity and maintains a high content of $\alpha$ tocopherol when exposed to short-term $\mathrm{NaCl}$ treatment [195]. The leaves contain high levels of vitamins, proteins, and minerals [196]. Several minerals (Na, K, Ca, Mg, S) are detected in leaves - as are micronutrients such as Fe, Zn, and B-depending on salt level concentrations [57]. The ratio of $\mathrm{Ca} / \mathrm{P}$ (about 1.0) is considered a good value for good $\mathrm{Ca}$ and $\mathrm{P}$ intestinal absorption. Oxalic acid content and the oxalic acid/Ca ratio are high in C. maritima, while the ratio of $\mathrm{K} / \mathrm{Na}$ is low [196].

Plant mycobiota

Many mycotoxigenic Alternaria species (e.g., A. alternata, A. mali, A. arborescens) were isolated from fresh tissues of C. maritima in Tunisia. The Alternaria population showed that most of the strains (90\%) produced at least one of four assessed mycotoxins (alternariol, alternariol methyl ether, tenuazonic acid, and altenuene), sometimes at very high levels [131]. 


\section{Appendix C}

PORTULACACEAE Juss.-Monotypic taxon that only contains the genus Portulaca. Dicotyledons, succulent annual herbs growing flat on the ground. Small, fat leaves. Small flowers with 2 sepals, 5 to 7 short-lived petals, and typically 6 to 40 stamens (sometimes more or less). Fruit is capsule. Sub cosmopolitan.

\section{Portulaca oleracea L. subsp. oleracea. Xerophyte}

\section{Botanical traits}

Biological form: therophyte.

Morphological characteristics: stems are round, thick, succulent and mostly prostrate. They range in colour from light green to reddish brown. The leaves are alternate or nearly opposite and sessile along the stems. The leaves are rather thick and succulent. The small, yellow flowers occur singly or in small, terminal clusters, and consist of five yellow petals and two green sepals. Fruit is capsule and splits open around the middle.

Habitat: ruderal areas and occasionally in salty soils.

Chorological type: (Sub-Cosmopol.) Cryptogenic.

Flowering period: May-October

Biochemical traits

Portulaca oleracea is an underutilized halophyte plant, already consumed as a vegetable in a variety of ways around thew world [197]. Nowadays, it is rich in omega-3 and omega-6 fatty acids ( $\omega-3$ and $\omega-6-F A s)$ as well as proteins, carbohydrates, carotenoids, vitamins A and C, and minerals [198]. Secondary metabolites are also present in the whole plant (leaves, stems, and roots) with a high content of phenolic compounds, especially lignans, which are important for ethno-pharmaceutical use [198]. The extract of this species is considered a potential source of melanosis-inhibiting compounds, for its diphenol oxidaseinhibiting activity [199]. Recently, microgreens of purslane have been produced under salinity to emphasize the potentiality of this plant cultivation; the content of total phenolics, flavonoids, carotenoids, and fatty acids, as well as the total antioxidant capacity content, are positively affected by salinity in $P$. oleracea microgreens grown with $80 \mathrm{mM} \mathrm{NaCl}$ in the nutrient solution [81].

\section{Plant mycobiota}

Some culturable endophytic fungi of P. oleracea, collected from Hohhot, Inner Mongolia, belonged to the genera Penicillium and Fusarium [200]. Fusarium solani was the most common species identified on the roots of P. oleracea, collected from the El-Kharga Oasis in Egypt. In addition, the entomopathogenic fungus Beauveria bassiana was found in leaf tissue for the first time in 2021 [201].

\section{References}

1. Atzori, G.; Mancuso, S.; Masi, E. Seawater Potential Use in Soilless Culture: A Review. Sci. Hortic. 2019, 249, 199-207. [CrossRef]

2. Ventura, Y.; Eshel, A.; Pasternak, D.; Sagi, M. The Development of Halophyte-Based Agriculture: Past and Present. Ann. Bot. 2015, 115, 529-540. [CrossRef] [PubMed]

3. Yuan, F.; Guo, J.; Shabala, S.; Wang, B. Reproductive Physiology of Halophytes: Current Standing. Front. Plant Sci. 2019, 9, 1954. [CrossRef] [PubMed]

4. van Zelm, E.; Zhang, Y.; Testerink, C. Salt Tolerance Mechanisms of Plants. Annu. Rev. Plant Biol. 2020, 71, 403-433. [CrossRef] [PubMed]

5. Wani, S.H.; Kumar, V.; Khare, T.; Guddimalli, R.; Parveda, M.; Solymosi, K.; Suprasanna, P.; Kavi Kishor, P.B. Engineering Salinity Tolerance in Plants: Progress and Prospects. Planta 2020, 251, 76. [CrossRef] [PubMed]

6. Ventura, Y.; Wuddineh, W.A.; Myrzabayeva, M.; Alikulov, Z.; Khozin-Goldberg, I.; Shpigel, M.; Samocha, T.M.; Sagi, M. Effect of Seawater Concentration on the Productivity and Nutritional Value of Annual Salicornia and Perennial Sarcocornia Halophytes as Leafy Vegetable Crops. Sci. Hortic. 2011, 128, 189-196. [CrossRef]

7. Barreira, L.; Resek, E.; Rodrigues, M.J.; Rocha, M.I.; Pereira, H.; Bandarra, N.; da Silva, M.M.; Varela, J.; Custódio, L. Halophytes: Gourmet Food with Nutritional Health Benefits? J. Food Comp. Anal. 2017, 59, 35-42. [CrossRef]

8. Urbano, M.; Tomaselli, V.; Bisignano, V.; Veronico, G.; Hammer, K.; Laghetti, G. Salicornia patula Duval-Jouve: From Gathering of Wild Plants to Some Attempts of Cultivation in Apulia Region (Southern Italy). Gen. Res. Crop Evol. 2017, 64, 1465-1472. [CrossRef] 
9. Custódio, M.; Villasante, S.; Calado, R.; Lillebø, A.I. Testing the Hydroponic Performance of the Edible Halophyte Halimione portulacoides, a Potential Extractive Species for Coastal Integrated Multi-Trophic Aquaculture. Sci. Total Environ. 2021, 766, 144378. [CrossRef]

10. Centofanti, T.; Bañuelos, G. Practical Uses of Halophytic Plants as Sources of Food and Fodder. In Halophytes and Climate Change: Adaptive Mechanisms and Potential Uses; CABI: Wallingford, UK, 2019; pp. 324-342.

11. Castañeda-Loaiza, V.; Oliveira, M.; Santos, T.; Schüler, L.; Lima, A.R.; Gama, F.; Salazar, M.; Neng, N.R.; Nogueira, J.M.F.; Varela, J.; et al. Wild vs Cultivated Halophytes: Nutritional and Functional Differences. Food Chem. 2020, 333, 127536. [CrossRef]

12. Petropoulos, S.A.; Karkanis, A.; Martins, N.; Ferreira, I.C.F.R. Edible Halophytes of the Mediterranean Basin: Potential Candidates for Novel Food Products. Trends Food Sci. Technol. 2018, 74, 69-84. [CrossRef]

13. Demir Aynur and Tprdamaz, R. Halophytes as Medicinal Herbs. In Handbook of Halophytes: From Molecules to Ecosystems towards Biosaline Agriculture; Grigore, M.-N., Ed.; Springer International Publishing: Cham, Switzerland, 2020; pp. 1-23. ISBN 978-3-030-17854-3. [CrossRef]

14. Labiad, M.H.; Giménez, A.; Varol, H.; Tüzel, Y.; Egea-Gilabert, C.; Fernández, J.A.; del Carmen Martínez-Ballesta, M. Effect of Exogenously Applied Methyl Jasmonate on Yield and Quality of Salt-Stressed Hydroponically Grown Sea Fennel (Crithmum Maritimum L.). Agronomy 2021, 11, 1083. [CrossRef]

15. Custódio, M.; Lillebø, A.I.; Calado, R.; Villasante, S. Halophytes as Novel Marine Products-A Consumers' Perspective in Portugal and Policy Implications. Mar. Policy 2021, 133, 104731. [CrossRef]

16. Grigore, M.-N.; Toma, C. Anatomical Adaptations of Halophytes; Springer International Publishing: Cham, Switzerland, 2017; ISBN 978-3-319-66479-8.

17. Rahman, M.M.; Mostofa, M.G.; Keya, S.S.; Siddiqui, M.N.; Ansary, M.M.U.; Das, A.K.; Rahman, M.A.; Tran, L.S.-P. Adaptive Mechanisms of Halophytes and Their Potential in Improving Salinity Tolerance in Plants. Int. J. Mol. Sci. 2021, 22, 10733. [CrossRef] [PubMed]

18. Yensen, N.P. Halophyte Uses for the Twenty-First Century. In Ecophysiology of High Salinity Tolerant Plants; Springer: Dordrecht, The Netherlands, 2006; pp. 367-396.

19. Uphof, J.C.T. Halophytes. Bot. Rev. 1941, 7, 1-58. [CrossRef]

20. Strogonov, B.M. Structure and Function of Plant Cells in Saline Habitats-New Trends in the Study of Salt Tolerance (Translated from Russian by A. Mercado); John Wiley and Sons: New York, NY, USA, 1973.

21. Stocker, O. Das Halophyten Problem. In Ergebnisse der Biologie; Springer: Berlin/Heidelberg, Germany, 1928 ; pp. $265-353$.

22. Lielh, H.; Al, A.; le Houerou, R.N. Salt-Tolerant Plants for the Arid Regions of the Mediterranean Isoclimatic Zone; Springer: Dordrecht, The Netherlands, 1993.

23. Glenn, E.P.; Brown, J.J.; Blumwald, E. Salt Tolerance and Crop Potential of Halophytes. Crit. Rev. Plant Sci. 1999, 18, $227-255$. [CrossRef]

24. The University of Sussex and Other Contributors EHALOPH—Halophytes Database—Version 3.22. Available online: https: //www.sussex.ac.uk/affiliates/halophytes/index.php (accessed on 3 November 2021).

25. Aronson, J.A. HALOPH: A Data Base of Salt Tolerant Plants of the World, 1st ed.; Office of Arid Lands Studies, University of Arizona: Tucson, AZ, USA, 1989.

26. Santos, J.; Al-Azzawi, M.; Aronson, J.; Flowers, T.J. EHALOPH a Database of Salt-Tolerant Plants: Helping Put Halophytes to Work. Plant Cell Physiol. 2016, 57, e10. [CrossRef]

27. Cheeseman, J.M. The Evolution of Halophytes, Glycophytes and Crops, and Its Implications for Food Security under Saline Conditions. New Phytol. 2015, 206, 557-570. [CrossRef]

28. Janssen, J.A.M.; Rodwell, J.S.; García Criado, M.; Gubbay, S.; Haynes, T.; Nieto, A.; Sanders, N.; Calix, M. European Red List of Habitats, 1st ed.; Commission, E., Ed.; Publications Office of the European Union: Luxembourg, 2016; ISBN 9789279615887.

29. FAO. Salt-Affected Soils. Available online: http://www.fao.org/soils-portal/soil-management/management-of-some-problemsoils/salt-affected-soils/more-information-on-salt-affected-soils/en/2018 (accessed on 15 September 2021).

30. Colla, G.; Roupahel, Y.; Cardarelli, M.; Rea, E. Effect of Salinity on Yield, Fruit Quality, Leaf Gas Exchange, and Mineral Composition of Grafted Watermelon Plants. HortScience 2006, 41, 622-627. [CrossRef]

31. Karakas, S.; Bolat, I.; Dikilitas, M. The Use of Halophytic Companion Plant (Portulaca oleracea L.) on Some Growth, Fruit, and Biochemical Parameters of Strawberry Plants under Salt Stress. Horticulturae 2021, 7, 63. [CrossRef]

32. Waisel, Y. Biology of Halophytes, 1st ed.; Elsevier: Amsterdam, The Netherlands, 2012; p. 410.

33. Flowers, T.J.; Colmer, T.D. Plant Salt Tolerance: Adaptations in Halophytes. Ann. Bot. 2015, 115, 327-331. [CrossRef]

34. Guo, J.; Suo, S.; Wang, B.-S. Sodium Chloride Improves Seed Vigour of the Euhalophyte Suaeda salsa. Seed Sci. Res. 2015, 25, 335-344. [CrossRef]

35. Debez, A.; Hamed, K.B.; Grignon, C.; Abdelly, C. Salinity Effects on Germination, Growth, and Seed Production of the Halophyte Cakile maritima. Plant Soil 2004, 262, 179-189. [CrossRef]

36. Zhang, H.; Irving, L.J.; Tian, Y.; Zhou, D. Influence of Salinity and Temperature on Seed Germination Rate and the Hydrotime Model Parameters for the Halophyte, Chloris virgata, and the Glycophyte, Digitaria sanguinalis. S. Afr. J. Bot. 2012, 78, 203-210. [CrossRef]

37. Guo, J.; Du, M.; Lu, C.; Wang, B. NaCl Improves Reproduction by Enhancing Starch Accumulation in the Ovules of the Euhalophyte Suaeda salsa. BMC Plant Biol. 2020, 20, 262. [CrossRef] 
38. Zhang, S.; Song, J.; Wang, H.; Feng, G. Effect of Salinity on Seed Germination, Ion Content and Photosynthesis of Cotyledons in Halophytes or Xerophyte Growing in Central Asia. J. Plant Ecol. 2010, 3, 259-267. [CrossRef]

39. Balnokin, Y.V.; Kurkova, E.B.; Myasoedov, N.A.; Lun'kov, R.V.; Shamsutdinov, N.Z.; Egorova, E.A.; Bukhov, N.G. Structural and Functional State of Thylakoids in a Halophyte Suaeda altissima before and after Disturbance of Salt-Water Balance by Extremely High Concentrations of NaCl. Russ. J. Plant Physiol. 2004, 51, 815-821. [CrossRef]

40. Koyro, H.-W.; Geißler, N.; Hussin, S.; Huchzermeyer, B. Survival at Extreme Locations: Life Strategies of Halophytes-The Long Way from System Ecology, Whole Plant Physiology, Cell Biochemistry and Molecular Aspects Back to Sustainable Utilization at Field Sites. In Biosaline Agriculture and High Salinity Tolerance; Birkhäuser: Basel, Switzerland, 2008; pp. 1-20.

41. Flowers, T.J.; Muscolo, A. Introduction to the Special Issue: Halophytes in a Changing World. AoB Plants 2015, 7, plv020. [CrossRef]

42. Steiner, M. To the Ecology of the Salt March of the Nordost lichen United Countries of Nordamerika. Jahrb. Know Offer. 1934, 81, 94.

43. Chapman, V.J. The New Perspective in the Halophytes. Q. Rev. Biol. 1942, 17, 291-311. [CrossRef]

44. Grigore, M.; Toma, C. A Proposal for a New Halophytes Classification, Based on Integrative Anatomy Observations. Muz Olten. Craiova Stud. Şi Comun. Ştiinţele Nat. 2010, 26, 45-50.

45. Walter, H. Salinity Problems in the Acid Zones. The Adaptations of Plants to Saline Soils. Arid Zone Res. 1961, 14, 65-68.

46. Aslam, R.; Bostan, N.; Nabgha-e-Amen; Maria, M.; Safdar, W. A Critical Review on Halophytes: Salt Tolerant Plants. J. Med. Plant Res. 2011, 5, 7108-7118.

47. Lombardi, T.; Bedini, S.; Bertacchi, A. Germination Ecology of the Aromatic Halophyte Artemisia caerulescens L.: Influence of Abiotic Factors and Seed after-Ripening Time. Folia Geobot. 2019, 54, 115-124. [CrossRef]

48. Lombardi, T.; Bedini, S. Seed Germination Strategies of Mediterranean Halophytes under Saline Condition. In Handbook of Halophytes; Springer International Publishing: Cham, Switzerland, 2020; pp. 1-19. [CrossRef]

49. Bertacchi, A.; Lombardi, T.; Saggese, A.; Lazzeri, V. The Vegetation of a Relict Salt Marsh Area in the Pisan Coast in the Context of Brackish Wetlands of Tuscany. Plant Sociol. 2021, 58, 41-53. [CrossRef]

50. Frondoni, R.; Iberite, M. The Halophile Vegetation of the Sedimentary Coast of Lazio (Central Tyrrhenian District, Italy). Plant Biosyst. 2002, 136, 49-67. [CrossRef]

51. Bartolucci, F.; Peruzzi, L.; Galasso, G.; Albano, A.; Alessandrini, A.; Ardenghi, N.M.G.; Astuti, G.; Bacchetta, G.; Ballelli, S.; Banfi, E.; et al. An Updated Checklist of the Vascular Flora Native to Italy. Plant Biosyst. 2018, 152, 179-303. [CrossRef]

52. Byng, J.W.; Chase, M.W.; Christenhusz, M.J.; Fay, M.F.; Judd, W.S.; Mabberley, D.J.; Sennikov, A.N.; Soltis, D.E.; Soltis, P.S.; Stevens, P.F.; et al. An Update of the Angiosperm Phylogeny Group Classification for the Orders and Families of Flowering Plants: APG IV. The Angiosperm Phylogeny Group. Bot. J. Linn. Soc. 2016, 35, 1-20.

53. Guarrera, P.M.; Salerno, G.; Caneva, G. Food, Flavouring and Feed Plant Traditions in the Tyrrhenian Sector of Basilicata, Italy. J. Ethnobiol. Ethnomed. 2006, 2, 37. [CrossRef]

54. Simopoulos, A.P.; Artemis, D.; Simopoulos, P.B.R. Omega-3 Fatty Acids and Antioxidants in Edible Wild Plants. Biol. Res. 2004, 37, 263-277. [CrossRef]

55. Tardío, J.; Pardo-de-santayana, M.; Morales, R. Ethnobotanical Review of Wild Edible Plants in Spain. Bot. J. Linn. Soc. 2006, 152, 27-71. [CrossRef]

56. Tug, A.E.; Yaprak, G.N. Halophytes as a Potential Food Source. ANADOLU J. AARI 2017, 27, 78-81.

57. Agudelo, A.; Carvajal, M.; del Carmen Martinez-Ballesta, M. Halophytes of the Mediterranean Basin-Underutilized Species with the Potential to be Nutritious Crops in the Scenario of the Climate Change. Foods 2021, 10, 119. [CrossRef] [PubMed]

58. Meena, M.; Divyanshu, K.; Kumar, S.; Swapnil, P.; Zehra, A.; Shukla, V.; Yadav, M.; Upadhyay, R.S. Regulation of L-Proline Biosynthesis, Signal Transduction, Transport, Accumulation and Its Vital Role in Plants during Variable Environmental Conditions. Heliyon 2019, 5, e02952. [CrossRef]

59. Gupta, B.; Huang, B. Mechanism of Salinity Tolerance in Plants: Physiological, Biochemical, and Molecular Characterization. Int. J. Genom. 2014, 2014, 701596. [CrossRef] [PubMed]

60. Centofanti, T.; Bañuelos, G. Evaluation of the Halophyte Salsola soda as an Alternative Crop for Saline Soils High in Selenium and Boron. J. Environ. Manag. 2015, 157, 96-102. [CrossRef] [PubMed]

61. Oueslati, S.; Karray-Bouraoui, N.; Attia, H.; Rabhi, M.; Ksouri, R.; Lachaal, M. Physiological and Antioxidant Responses of Mentha pulegium (Pennyroyal) to Salt Stress. Acta Physiol. Plant 2010, 32, 289-296. [CrossRef]

62. Mzoughi, Z.; Abdelhamid, A.; Rihouey, C.; le Cerf, D.; Bouraoui, A.; Majdoub, H. Optimized Extraction of Pectin-like Polysaccharide from Suaeda fruticosa Leaves: Characterization, Antioxidant, Anti-Inflammatory and Analgesic Activities. Carbohydr. Polym. 2018, 185, 127-137. [CrossRef]

63. Guerrero, J.L.G.; Madrid, P.C.; Isasa, M.E.T. Mineral Elements Determination in Wild Edible Plants. Ecol. Food Nutr. 1999, 38, 209-222. [CrossRef]

64. Zhou, Y.-X.; Xin, H.-L.; Rahman, K.; Wang, S.-J.; Peng, C.; Zhang, H. Portulaca oleracea L.: A Review of Phytochemistry and Pharmacological Effects. Biomed. Res. Int. 2015, 2015, 925631. [CrossRef]

65. Fernández, J.A.; Orsini, F.; Baeza, E.; Oztekin, G.B.; Muñoz, P.; Contreras, J.; Montero, J.I. Current Trends in Protected Cultivation in Mediterranean Climates. Eur. J. Hortic. Sci. 2018, 83, 294-305. [CrossRef]

66. Savvas, D.; Gruda, N. Application of Soilless Culture Technologies in the Modern Greenhouse Industry-A Review. Eur. J. Hortic. Sci. 2018, 83, 280-293. [CrossRef] 
67. Kotzen, B.; Emerenciano, M.G.C.; Moheimani, N.; Burnell, G.M. Aquaponics: Alternative Types and Approaches. In Aquaponics Food Production Systems; Springer International Publishing: Cham, Switzerland, 2019; pp. 301-330.

68. Custódio, M.; Villasante, S.; Cremades, J.; Calado, R.; Lillebø, A. Unravelling the Potential of Halophytes for Marine Integrated Multi-Trophic Aquaculture (IMTA)-A Perspective on Performance, Opportunities and Challenges. Aquac. Environ. Interact. 2017, 9, 445-460. [CrossRef]

69. Singh, D.; Buhmann, A.K.; Flowers, T.J.; Seal, C.E.; Papenbrock, J. Salicornia as a Crop Plant in Temperate Regions: Selection of Genetically Characterized Ecotypes and Optimization of Their Cultivation Conditions. AoB Plants 2014, 6, plu071. [CrossRef]

70. Boni, A. Uno Studio Sulla Coltura Idroponica e la Conservazione Post-Raccolta della Salicornia Europaea. Master's Thesis, Department of Food Agriculture Environment, University of Pisa, Pisa, Italy, 2020.

71. Nie, L.; Feng, J.; Lü, S.; Jiang, P.; Fan, P.; Tai, F.; Li, Y. The Response of Euhalophyte Salicornia europaea L. to Different Nitrogen Forms. Acta Ecol. Sin. 2012, 32, 5703-5712. [CrossRef]

72. Lima, A.R.; Castañeda-Loaiza, V.; Salazar, M.; Nunes, C.; Quintas, C.; Gama, F.; Pestana, M.; Correia, P.J.; Santos, T.; Varela, J.; et al. Influence of Cultivation Salinity in the Nutritional Composition, Antioxidant Capacity and Microbial Quality of Salicornia ramosissima Commercially Produced in Soilless Systems. Food Chem. 2020, 333, 127525. [CrossRef]

73. Kong, Y.; Zheng, Y. Potential of Producing Salicornia bigelovii Hydroponically as a Vegetable at Moderate NaCl Salinity. Hortic. Sci. 2014, 49, 1154-1157. [CrossRef]

74. Beyer, C.P.; Gómez, S.; Lara, G.; Monsalve, J.P.; Orellana, J.; Hurtado, C.F. Sarcocornia neei: A Novel Halophyte Species for Bioremediation of Marine Aquaculture Wastewater and Production Diversification in Integrated Systems. Aquaculture 2021, 543, 736971. [CrossRef]

75. Doncato, K.B.; Costa, C.S.B. Micronutrient Supplementation Needs for Halophytes in Saline Aquaponics with BFT System Water. Aquaculture 2021, 531, 735815. [CrossRef]

76. Custódio, M.; Cartaxana, P.; Villasante, S.; Calado, R.; Lillebø, A.I. LED Lighting and High-Density Planting Enhance the Cost-Efficiency of Halimione portulacoides Extraction Units for Integrated Aquaculture. Appl. Sci. 2021, 11, 4995. [CrossRef]

77. Custódio, M.; Maciel, E.; Domingues, M.R.; Lillebø, A.I.; Calado, R. Nutrient Availability Affects the Polar Lipidome of Halimione portulacoides Leaves Cultured in Hydroponics. Sci. Rep. 2020, 10, 6583. [CrossRef] [PubMed]

78. Egea-Gilabert, C.; Ruiz-Hernández, M.V.; Parra, M.Á.; Fernández, J.A. Characterization of Purslane (Portulaca Oleracea L.) Accessions: Suitability as Ready-to-Eat Product. Sci. Hortic. 2014, 172, 73-81. [CrossRef]

79. Kong, Y.; Zheng, Y. Hydroponic Production of Purslane as a Sodium-Removing Vegetable in NaCl-Rich Nutrient Solution. HortScience 2014, 49, 201-206. [CrossRef]

80. Alu'datt, M.H.; Rababah, T.; Alhamad, M.N.; Al-Tawaha, A.; Al-Tawaha, A.R.; Gammoh, S.; Ereifej, K.I.; Al-Karaki, G.; Hamasha, H.R.; Tranchant, C.C.; et al. Herbal Yield, Nutritive Composition, Phenolic Contents and Antioxidant Activity of Purslane (Portulaca oleracea L.) Grown in Different Soilless Media in a Closed System. Ind. Crops Prod. 2019, 141, 111746. [CrossRef]

81. Giménez, A.; Martínez-Ballesta, M.D.C.; Egea-Gilabert, C.; Gómez, P.A.; Artés-Hernández, F.; Pennisi, G.; Orsini, F.; Crepaldi, A.; Fernández, J.A. Combined Effect of Salinity and Led Lights on the Yield and Quality of Purslane (Portulaca oleracea L.) Microgreens. Horticulturae 2021, 7, 180. [CrossRef]

82. Mortley, D.G.; Oh, J.H.; Johnson, D.S.; Bonsi, C.K.; Hill, W.A. Influence of Harvest Intervals on Growth Responses and Fatty Acid Content of Purslane (Portulaca oleracea). HortScience 2012, 47, 437-439. [CrossRef]

83. Ventura, Y.; Sagi, M. Halophyte Crop Cultivation: The Case for Salicornia and Sarcocornia. Environ. Exp. Bot. 2013, 92, 144-153. [CrossRef]

84. Rouphael, Y.; Kyriacou, M.C. Enhancing Quality of Fresh Vegetables through Salinity Eustress and Biofortification Applications Facilitated by Soilless Cultivation. Front. Plant. Sci. 2018, 9, 1254. [CrossRef]

85. Oztekin, G.B.; Uludag, T.; Tuzel, Y. Impact of Nutrient Solution Concentration and Growth Period on Baby Leaf Purslane Production in Floating System. Acta Hortic. 2020, 1273, 65-74. [CrossRef]

86. Nicola, S.; Egea-Gilabert, C.; Niñirola, D.; Conesa, E.; Pignata, G.; Fontana, E.; Fernández, J.A. Nitrogen and Aeration Levels of the Nutrient Solution in Soilless Cultivation Systems as Important Growing Conditions Affecting Inherent Quality of Baby Leaf Vegetables: A Review. Acta Hortic. 2015, 167-177. [CrossRef]

87. Ceccanti, C.; Landi, M.; Incrocci, L.; Pardossi, A.; Venturi, F.; Taglieri, I.; Ferroni, G.; Guidi, L. Comparison of Three Domestications and Wild-Harvested Plants for Nutraceutical Properties and Sensory Profiles in Five Wild Edible Herbs: Is Domestication Possible? Foods 2020, 9, 1065. [CrossRef] [PubMed]

88. Kong, Y.; Zheng, Y. Suaeda glauca Can Be Produced Hydroponically at Moderate NACL Salinity. HortScience 2015, 50, 847-850. [CrossRef]

89. Santamaria, P. Nitrate in Vegetables: Toxicity, Content, Intake and EC Regulation. J. Sci. Food Agric. 2006, 86, 10-17. [CrossRef]

90. Natesh, H.N.; Abbey, L.; Asiedu, S.K. An Overview of Nutritional and Anti Nutritional Factors in Green Leafy Vegetables. Hortic. Int. J. 2017, 1, 58-65. [CrossRef]

91. Manzocco, L.; Foschia, M.; Tomasi, N.; Maifreni, M.; Dalla Costa, L.; Marino, M.; Cortella, G.; Cesco, S. Influence of Hydroponic and Soil Cultivation on Quality and Shelf Life of Ready-to-Eat Lamb's Lettuce (Valerianella locusta L. Laterr). J. Sci. Food Agric. 2011, 91, 1373-1380. [CrossRef] 
92. Ciriello, M.; Formisano, L.; Pannico, A.; El-Nakhel, C.; Fascella, G.; Duri, L.G.; Cristofano, F.; Gentile, B.R.; Giordano, M.; Rouphael, Y.; et al. Nutrient Solution Deprivation as a Tool to Improve Hydroponics Sustainability: Yield, Physiological, and Qualitative Response of Lettuce. Agronomy 2021, 11, 1469. [CrossRef]

93. Urrestarazu, M.; Postigo, A.; Salas, M.; Sánchez, A.; Carrasco, G. Nitrate Accumulation Reduction Using Chloride in the Nutrient Solution on Lettuce Growing by NFT in Semiarid Climate Conditions. J. Plant Nutr. 1998, 21, 1705-1714. [CrossRef]

94. Mori, S.; Kobayashi, N.; Arao, T.; Higuchi, K.; Maeda, Y.; Yoshiba, M.; Tadano, T. Enhancement of Nitrate Reduction by Chlorine Application in Suaeda salsa (L.) Pall. Soil Sci. Plant Nutr. 2008, 54, 903-909. [CrossRef]

95. He, J.; You, X.; Qin, L. High Salinity Reduces Plant Growth and Photosynthetic Performance but Enhances Certain Nutritional Quality of Halophyte Portulaca oleracea L. Grown Hydroponically Under LED Lighting. Front. Plant Sci. 2021, 12, 457. [CrossRef]

96. Abrol, I.P.; Massoud, F.I.; Yadav, J.S.P. Salt-Affected Soils and Their Management. In Food and Agriculture Organization of the United Nations (FAO) Soils Bulletin; FAO: Rome, Italy, 1988; No. 39.

97. Yuan, F.; Xu, Y.; Leng, B.; Wang, B. Beneficial Effects of Salt on Halophyte Growth: Morphology, Cells, and Genes. Open Life Sci. 2019, 14, 191-200. [CrossRef]

98. WHO. World Health Organization Guideline: Sodium Intake for Adults and Children; WHO: Geneva, Switzerland, $2012 ;$ pp. 1-56.

99. Lopes, M.; Cavaleiro, C.; Ramos, F. Sodium Reduction in Bread: A Role for Glasswort (Salicornia ramosissima J. Woods). Compr. Rev. Food Sci. Food Saf. 2017, 16, 1056-1071. [CrossRef] [PubMed]

100. Seong, P.N.; Seo, H.W.; Cho, S.H.; Kim, Y.S.; Kang, S.M.; Kim, J.H.; Kang, G.H.; Park, B.Y.; Moon, S.S.; Hoa, V.B. Potential Use of Glasswort Powder as a Salt Replacer for the Production of Healthier Dry-Cured Ham Products. Czech J. Food Sci. 2017, 35, 149-159. [CrossRef]

101. Savage, G.; Klunklin, W. Oxalates Are Found in Many Different European and Asian Foods-Effects of Cooking and Processing. J. Food Res. 2018, 7, 76. [CrossRef]

102. Siener, R.; Hönow, R.; Seidler, A.; Voss, S.; Hesse, A. Oxalate Contents of Species of the Polygonaceae, Amaranthaceae and Chenopodiaceae Families. Food Chem. 2006, 98, 220-224. [CrossRef]

103. Marcason, W. Where Can I Find Information on the Oxalate Content of Foods? J. Am. Diet. Assoc. 2006, 106, 627-628. [CrossRef]

104. Uddin, M.M.; Chen, Z.; Huang, L. Cadmium Accumulation, Subcellular Distribution and Chemical Fractionation in Hydroponically Grown Sesuvium portulacastrum [Aizoaceae]. PLoS ONE 2021, 15, e0244085. [CrossRef]

105. Fontana, E.; Hoeberechts, J.; Nicola, S.; Cros, V.; Palmegiano, G.B.; Peiretti, P.G. Nitrogen Concentration and Nitrate/Ammonium Ratio Affect Yield and Change the Oxalic Acid Concentration and Fatty Acid Profile of Purslane (Portulaca oleracea L.) Grown in a Soilless Culture System. J. Sci. Food Agric. 2006, 86, 2417-2424. [CrossRef]

106. Kaşkar, Ç.; Fernándeza, J.A.; Ochoa, J.; Niñirola, D.; Conesa, E.; Tüzel, Y. Agronomic Behaviour and Oxalate and Nitrate Content of Different Purslane Cultivars (Portulaca oleracea) Grown in a Hydroponic Floating System. Acta Hortic. 2009, 807, 521-526. [CrossRef]

107. Guil, J.L.; Rodríguez-Garcí, I.; Torija, E. Nutritional and Toxic Factors in Selected Wild Edible Plants. Plant Foods Hum. Nutr. 1997, 51, 99-107. [CrossRef]

108. Carvalho, I.S.; Teixeira, M.; Brodelius, M. Effect of Salt Stress on Purslane and Potential Health Benefits: Oxalic Acid and Fatty Acids Profile. In Proceedings of the International Plant Nutrition Colloquium XVI, U.C Davis, Sacramento, CA, USA, 26-30 August 2009.

109. Szalai, G.; Dai, N.; Danin, A.; Dudai, N.; Barazani, O. Effect of Nitrogen Source in the Fertilizing Solution on Nutritional Quality of Three Members of the Portulaca oleracea Aggregate. J. Sci. Food Agric. 2010, 90, 2039-2045. [CrossRef]

110. Palaniswamy, U.R.; Bible, B.B.; McAvoy, R.J. Oxalic Acid Concentrations in Purslane (Portulaca oleraceae L.) Is Altered by the Stage of Harvest and the Nitrate to Ammonium Ratios in Hydroponics. Sci. Hortic. 2004, 102, 267-275. [CrossRef]

111. Ponzilacqua, B.; Rottinghaus, G.E.; Landers, B.R.; Oliveira, C.A.F. Effects of Medicinal Herb and Brazilian Traditional Plant Extracts on in Vitro Mycotoxin Decontamination. Food Control 2019, 100, 24-27. [CrossRef]

112. Medina, Á.; Rodríguez, A.; Magan, N. Climate Change and Mycotoxigenic Fungi: Impacts on Mycotoxin Production. Curr. Opin. Food Sci. 2015, 5, 99-104. [CrossRef]

113. Alshannaq, A.; Yu, J.H. Occurrence, Toxicity, and Analysis of Major Mycotoxins in Food. Int. J. Environ. Res. Public Health 2017, 14, 632. [CrossRef] [PubMed]

114. Drusch, S.; Ragab, W. Mycotoxins in Fruits, Fruit Juices, and Dried Fruits. J. Food Prot. 2003, 66, 1514-1527. [CrossRef] [PubMed]

115. Enikova, R.K.; Stoynovska, M.R.; Karcheva, M.D. Mycotoxins in Fruits and Vegetables. J. IMAB 2020, 26, 3139-3143. [CrossRef]

116. Yeni, F.; Yavaş, S.; Alpas, H.; Soyer, Y. Most Common Foodborne Pathogens and Mycotoxins on Fresh Produce: A Review of Recent Outbreaks. Crit. Rev. Food Sci. Nutr. 2016, 56, 1532-1544. [CrossRef]

117. Paster, N.; Barkai-Golan, R. Mouldy Fruits and Vegetables as a Source of Mycotoxins: Part 2. World Mycotoxin J. 2008, 1, 385-396. [CrossRef]

118. Restani, P. Diffusion of Mycotoxins in Fruits and Vegetables. In Mycotoxins Fruits Veg; Barkai-Golan, R., Paster, N., Eds.; Elsevier: San Diego, CA, USA, 2008; pp. 105-114. ISBN 9780123741264.

119. Strobel, G.A. Endophytes as Sources of Bioactive Products. Microbes Infect. 2003, 5, 535-544. [CrossRef]

120. Zhang, H.W.; Song, Y.C.; Tan, R.X. Biology and Chemistry of Endophytes. Nat. Prod. Rep. 2006, 23, 753-771. [CrossRef]

121. Mousa, W.K.; Raizada, M.N. The Diversity of Anti-Microbial Secondary Metabolites Produced by Fungal Endophytes: An Interdisciplinary Perspective. Front. Microbiol. 2013, 4, 65. [CrossRef] [PubMed] 
122. Manganiello, G.; Marra, R.; Staropoli, A.; Lombardi, N.; Vinale, F.; Nicoletti, R. The Shifting Mycotoxin Profiles of Endophytic Fusarium Strains: A Case Study. Agriculture 2019, 9, 143. [CrossRef]

123. Thirumalai, E.; Venkatachalam, A.; Suryanarayanan, T.S. Fungal Endophytes of Betel Leaves: The Need to Study MycotoxinProducing Endophytes in Leafy Vegetables. Sydowia 2020, 66, 2. [CrossRef]

124. Cantrell, S.A.; Casillas-Martínez, L.; Molina, M. Characterization of Fungi from Hypersaline Environments of Solar Salterns Using Morphological and Molecular Techniques. Mycol. Res. 2006, 110, 962-970. [CrossRef]

125. Biango-Daniels, M.N.; Hodge, K.T. Sea Salts as a Potential Source of Food Spoilage Fungi. Food Microbiol. 2018, 69, 89-95. [CrossRef]

126. Maciá-Vicente, J.G.; Jansson, H.B.; Abdullah, S.K.; Descals, E.; Salinas, J.; Lopez-Llorca, L. v Fungal Root Endophytes from Natural Vegetation in Mediterranean Environments with Special Reference to Fusarium spp. FEMS Microbiol. Ecol. 2008, 64, 90-105. [CrossRef] [PubMed]

127. Calabon, M.S.; Jones, E.B.G.; Promputtha, I.; Hyde, K.D. Fungal Biodiversity in Salt Marsh Ecosystems. J. Fungi 2021, 7, 648. [CrossRef]

128. Bell, A.A.; Wheeler, M.H. Biosynthesis and Functions of Fungal Melanins. Annu. Rev. Phytopathol. 1986, 24, 411-451. [CrossRef]

129. Papizadeh, M.; Wijayawardene, N.N.; Amoozegar, M.A.; Saba, F.; Fazeli, S.A.S.; Hyde, K.D. Neocamarosporium jorjanensis, N. persepolisi, and N. Solicola spp. nov. (Neocamarosporiaceae, Pleosporales) Isolated from Saline Lakes of Iran Indicate the Possible Halotolerant Nature for the Genus. Mycol. Prog. 2018, 17, 661-679. [CrossRef]

130. Gonçalves, M.F.M.; Aleixo, A.; Vicente, T.F.L.; Esteves, A.C.; Alves, A. Three New Species of Neocamarosporium Isolated from Saline Environments: N. aestuarinum sp. nov., N. endophyticum sp. nov. and N. halimiones sp. nov. Mycosphere 2019, 10, 608-621. [CrossRef]

131. Chalbi, A.; Sghaier-Hammamil, B.; Meca, G.; Quiles, J.M.; Abdelly, C.; Marangi, C.; Logrieco, A.N.F.; Moretti, A.; Masiello, M. Characterization of Mycotoxigenic Alternaria Species Isolated from the Tunisian Halophyte Cakile maritima. Phytopathol. Mediterr. 2020, 59, 107-118. [CrossRef]

132. Lopes, M.; da Conceição Castilho, M.; Sanches-Silva, A.; Freitas, A.; Barbosa, J.; Gonçalves, M.J.; Cavaleiro, C.; Ramos, F. Evaluation of the Mycotoxins Content of Salicornia spp.: A Gourmet Plant Alternative to Salt. Food Addit. Contam. Part B Surveill. 2020, 13, 162-170. [CrossRef]

133. Murphy, P.A.; Hendrich, S.; Landgren, C.; Bryant, C.M. Food Mycotoxins: An Update. J. Food Sci. 2006, 71, R51-R65. [CrossRef]

134. Bhat, R.; Rai, R.V.; Karim, A.A. Mycotoxins in Food and Feed: Present Status and Future Concerns. Compr. Rev. Food Sci. Food Saf. 2010, 9, 57-81. [CrossRef] [PubMed]

135. Carstens, C.K.; Salazar, J.K.; Darkoh, C. Multistate Outbreaks of Foodborne Illness in the United States Associated with Fresh Produce From 2010 to 2017. Front. Microbiol. 2019, 10, 2667. [CrossRef]

136. Olaimat, A.N.; Abu Ghoush, M.; Al-Holy, M.; Abu Hilal, H.; Al-Nabulsi, A.A.; Osaili, T.M.; Ayyash, M.; Holley, R.A. Survival and Growth of Listeria monocytogenes and Staphylococcus aureus in Ready-to-Eat Mediterranean Vegetable Salads: Impact of Storage Temperature and Food Matrix. Int. J. Food Microbiol. 2021, 346, 109149. [CrossRef] [PubMed]

137. European Commission (EC) Regulation No 1441/2007 of 5 December 2007 Amending Regulation (EC) No 2073/2005 on Microbiological Criteria for Foodstuffs. Off. J. Eur. Union 2007, L322, 12-29.

138. Castro-Ibáñez, I.; Gil, M.I.; Allende, A. Ready-to-Eat Vegetables: Current Problems and Potential Solutions to Reduce Microbial Risk in the Production Chain. LWT-Food Sci. Technol. 2017, 85, 284-292. [CrossRef]

139. Aiyedun, S.O.; Onarinde, B.A.; Swainson, M.; Dixon, R.A. Foodborne Outbreaks of Microbial Infection from Fresh Produce in Europe and North America: A Systematic Review of Data from This Millennium. Int. J. Food Sci. Technol. 2021, 56, 2215-2223. [CrossRef]

140. Kadereit, G.; Piirainen, M.; Lambinon, J.; Vanderpoorten, A. Cryptic Taxa Should Have Names: Reflections in the Glasswort Genus Salicornia (Amaranthaceae). TAXON 2012, 61, 1227-1239. [CrossRef]

141. Steffen, S.; Ball, P.; Mucina, L.; Kadereit, G. Phylogeny, Biogeography and Ecological Diversification of Sarcocornia (Salicornioideae, Amaranthaceae). Ann. Bot. 2015, 115, 353-368. [CrossRef] [PubMed]

142. Piirainen, M.; Salicornia. In Euro+Med Plantbase-The Information Resource for Euro-Mediterranean Plant Diversity. Available online: http:/ / ww2.bgbm.org/EuroPlusMed/PTaxonDetail.asp?NameCache=Salicornia+europaea\#2 (accessed on 20 February 2022).

143. Lv, S.; Jiang, P.; Chen, X.; Fan, P.; Wang, X.; Li, Y. Multiple Compartmentalization of Sodium Conferred Salt Tolerance in Salicornia europaea. Plant Physiol. Biochem. 2012, 51, 47-52. [CrossRef] [PubMed]

144. Shin, J.H.; Boo, H.O.; Jeon, M.W.; KO, J.Y. Chemical Components of Native Plant, Salicornia herbacea L. Korean J. Plant Res. 2002, 15, 216-220.

145. Wang, X.; Bai, J.; Wang, W.; Zhang, G.; Yin, S.; Wang, D. A Comparative Metabolomics Analysis of the Halophyte Suaeda salsa and Salicornia europaea. Environ. Geochem. Health 2021, 43, 1109-1122. [CrossRef]

146. Araus, J.L.; Rezzouk, F.Z.; Thushar, S.; Shahid, M.; Elouafi, I.A.; Bort, J.; Serret, M.D. Effect of Irrigation Salinity and Ecotype on the Growth, Physiological Indicators and Seed Yield and Quality of Salicornia europaea. Plant Sci. 2021, 304, 110819. [CrossRef] [PubMed]

147. Aghaleh, M.; Niknam, V.; Ebrahimzadeh, H.; Razavi, K. Salt Stress Effects on Growth, Pigments, Proteins and Lipid Peroxidation in Salicornia persica and S. europaea. Biol. Plant 2009, 53, 243-248. [CrossRef] 
148. Aghaleh, M.; Niknam, V.; Ebrahimzadeh, H.; Razavi, K. Antioxidative Enzymes in Two in Vitro Cultured Salicornia Species in Response to Increasing Salinity. Biol. Plant 2014, 58, 391-394. [CrossRef]

149. Patel, S. Salicornia: Evaluating the Halophytic Extremophile as a Food and a Pharmaceutical Candidate. 3 Biotech 2016, 6, 104. [CrossRef]

150. Essaidi, I.; Brahmi, Z.; Snoussi, A.; ben Haj Koubaier, H.; Casabianca, H.; Abe, N.; el Omri, A.; Chaabouni, M.M.; Bouzouita, N. Phytochemical Investigation of Tunisian Salicornia herbacea L., Antioxidant, Antimicrobial and Cytochrome P450 (CYPs) Inhibitory Activities of Its Methanol Extract. Food Control 2013, 32, 125-133. [CrossRef]

151. Furtado, B.U.; Szymańska, S.; Hrynkiewicz, K. A Window into Fungal Endophytism in Salicornia europaea: Deciphering Fungal Characteristics as Plant Growth Promoting Agents. Plant Soil 2019, 445, 577-594. [CrossRef]

152. Furtado, B.U.; Gołebiewski, M.; Skorupa, M.; Hulisz, P.; Hrynkiewicz, K. Bacterial and Fungal Endophytic Microbiomes of Salicornia europaea. Appl. Environ. Microbiol. 2019, 85, e00305-19. [CrossRef] [PubMed]

153. Okane, I.; Nakagiri, A. Assemblages of Endophytic Fungi on Salicornia europaea Disjunctively Distributed in Japan: Towards Clarification of the Ubiquity of Fungal Endophytes on Halophytes and Their Ecological Roles. Curr. Sci. 2015, 109, 62-71. [CrossRef]

154. Yucel, C.; Farhan, M.; Khairo, A.; Ozer, G.; Cetin, M.; Ortas, I.; Islam, K. Evaluating Salicornia as a Potential Forage Crop to Remediate High Groundwater-Table Saline Soil under Continental Climates. Int. J. Plant Soil Sci. 2017, 16, 1-10. [CrossRef]

155. Petrini, O.; Fisher, P.J. Fungal Endophytes in Salicornia perennis. Trans. Br. Mycol. Soc. 1986, 87, 647-651. [CrossRef]

156. Boulos, L. Notes on Suaeda Forssk. Ex Scop. Studies in the Chenopodiaceae of Arabia: 2. Kew Bull. 1991, 46, 291. [CrossRef]

157. Wang, S.-M.; Zhang, J.-L.; Flowers, T.J. Low-Affinity Na ${ }^{+}$Uptake in the Halophyte Suaeda maritima. Plant Physiol. 2007, 145, 559-571. [CrossRef]

158. 158. The European Parliament, the European Council. Regulation (EU) No 1169/2011 of 25 October 2011 on the provision of food information to consumers, 2011. Off. J. Eur. Union, 2011; L 304, 18-63.

159. D'Ambrosio, C.; Stigliani, A.L.; Giorio, G. Food from Genetically Engineered Plants: Tomato with Increased $\beta$-Carotene, Lutein, and Xanthophylls Contents. In Genetically Modified Organisms in Food: Production, Safety, Regulation and Public Health; Watson, R.R., Preedy, V.R., Eds.; Elsevier Inc.: London, UK, 2015; pp. 361-380. ISBN 978-012802259-7/978-012802530-7.

160. US Department of Agriculture (USDA); Agricultural Research Service; Nutrient Data Laboratory. Composition of Foods: Raw, Processed, Prepared. USDA National Nutrient Database for Standard Reference, Legacy (2018). Documentation and User Guide; USDA: Beltsville, MD, USA, 2018.

161. Khalmuratova, I.; Choi, D.H.; Woo, J.R.; Jeong, M.J.; Oh, Y.; Kim, Y.G.; Lee, I.J.; Choo, Y.S.; Kim, J.G. Diversity and Plant Growth-Promoting Effects of Fungal Endophytes Isolated from Salt-Tolerant Plants. J. Microbiol. Biotechnol. 2020, 30, 1680-1687. [CrossRef]

162. Khalmuratova, I.; Kim, H.; Nam, Y.J.; Oh, Y.; Jeong, M.J.; Choi, H.R.; You, Y.H.; Choo, Y.S.; Lee, I.J.; Shin, J.H.; et al. Diversity and Plant Growth Promoting Capacity of Endophytic Fungi Associated with Halophytic Plants from the West Coast of Korea. Mycobiology 2015, 43, 373-383. [CrossRef]

163. Suryanarayanan, T.S.; Kumaresan, V. Endophytic Fungi of Some Halophytes from an Estuarine Mangrove Forest. Mycol. Res. 2000, 104, 1465-1467. [CrossRef]

164. Hameed, A.; Hussain, T.; Gulzar, S.; Aziz, I.; Gul, B.; Khan, M.A. Salt Tolerance of a Cash Crop Halophyte Suaeda Fruticosa: Biochemical Responses to Salt and Exogenous Chemical Treatments. Acta Physiol. Plant 2012, 34, 2331-2340. [CrossRef]

165. Qasim, M.; Abideen, Z.; Adnan, M.Y.; Gulzar, S.; Gul, B.; Rasheed, M.; Khan, M.A. Antioxidant Properties, Phenolic Composition, Bioactive Compounds and Nutritive Value of Medicinal Halophytes Commonly Used as Herbal Teas. S. Afr. J. Bot. 2017, 110, 240-250. [CrossRef]

166. Shahi, M.; Saaghari, M.; Esfahan, E.Z.; Jaimand, K. Investigation on Potential of Suaeda fruticosa as a Source of Edible Oil. J. Biodivers. Environ. Sci. 2013, 3, 101-107.

167. Ozcan, T. Fatty Acid Composition of Seed Oils in Some Sand Dune Vegetation Species from Turkey. Chem. Nat. Compd. 2014, 50, 804-809. [CrossRef]

168. Ksouri, R.; Megdiche, W.; Debez, A.; Falleh, H.; Grignon, C.; Abdelly, C. Salinity Effects on Polyphenol Content and Antioxidant Activities in Leaves of the Halophyte Cakile maritima. Plant Physiol. Biochem. 2007, 45, 244-249. [CrossRef] [PubMed]

169. Fisher, P.J.; Petrini, O. Location of Fungal Endophytes in Tissues of Suaeda fruticosa: A Preliminary Study. Trans. Br. Mycol. Soc. 1987, 89, 246-249. [CrossRef]

170. Karakas, S.; Çullu, M.A.; Dikilitas, M. Comparison of Two Halophyte Species (Salsola soda and Portulaca oleracea) for Salt Removal Potential under Different Soil Salinity Conditions. Turk. J. Agric. For. 2017, 41, 183-190. [CrossRef]

171. Hamed, A.I.; Masullo, M.; Sheded, M.G.; Mahalel, U.A.; Tawfik, M.M.; Perrone, A.; Piacente, S. Triterpene Saponins from Salsola imbricata. Phytochem. Lett. 2011, 4, 353-356. [CrossRef]

172. Tundis, R.; Menichini, F.; Conforti, F.; Loizzo, M.R.; Bonesi, M.; Statti, G.; Menichini, F. A Potential Role of Alkaloid Extracts from Salsola Species (Chenopodiaceae) in the Treatment of Alzheimer's Disease. J. Enzym. Inhib. Med. Chem. 2009, 24, 818-824. [CrossRef]

173. Rasheed, D.M.; el Zalabani, S.M.; Koheil, M.A.; El-Hefnawy, H.M.; Farag, M.A. Metabolite Profiling Driven Analysis of Salsola Species and Their Anti-Acetylcholinesterase Potential. Nat. Prod. Res. 2013, 27, 2320-2327. [CrossRef] 
174. Iannuzzi, A.M.; Moschini, R.; de Leo, M.; Pineschi, C.; Balestri, F.; Cappiello, M.; Braca, A.; Del-Corso, A. Chemical Profile and Nutraceutical Features of Salsola soda (Agretti): Anti-Inflammatory and Antidiabetic Potential of Its Flavonoids. Food Biosci. 2020, 37, 100713. [CrossRef]

175. Tundis, R.; Loizzo, M.R.; Statti, G.A.; Menichini, F. Inhibitory Effects on the Digestive Enzyme Alpha-Amylase of Three Salsola Species (Chenopodiaceae) in Vitro. Pharmazie 2007, 62, 473-475. [PubMed]

176. Ungar, I.A. Effect of Salinity on Seed Germination, Growth, and Ion Accumulation of Atriplex patula (Chenopodiaceae). Am. J. Bot. 1996, 83, 604. [CrossRef]

177. Mann, E.; Rutter, A.; Zeeb, B. Evaluating the Efficacy of Atriplex spp. in the Phytoextraction of Road Salt (NaCl) from Contaminated Soil. Environ. Pollut. 2020, 265, 114963. [CrossRef] [PubMed]

178. Bylka, W. A New Acylated Flavonol Diglycoside from Atriplex littoralis. Acta Physiol. Plant 2004, 26, 393-398. [CrossRef]

179. Bueno, M.; Lendínez, M.L.; Aparicio, C.; Cordovilla, M.P. Effect of Salinity on Polyamines and Ethylene in Atriplex prostrata and Plantago coronopus. Biol. Plant 2015, 59, 596-600. [CrossRef]

180. Egan, T.P.; Ungar, I.A. Competition between Salicornia europaea and Atriplex prostrata (Chenopodiaceae) along an Experimental Salinity Gradient. Wetl. Ecol. Manag. 2004, 9, 457-461. [CrossRef]

181. Wang, L.; Showalter, A.; Ungar, I. Effect of Salinity on Growth, Ion Content, and Cell Wall Chemistry in Atriplex prostrata (Chenopodiaceae). Am. J. Bot. 1997, 84, 1247. [CrossRef]

182. Bueno, M.; Lendínez, M.L.; Calero, J.; del Pilar Cordovilla, M. Salinity Responses of Three Halophytes from Inland Saltmarshes of Jaén (Southern Spain). Flora 2020, 266, 151589. [CrossRef]

183. Bueno, M.; Lendínez, M.L.; Aparicio, C.; Cordovilla, M.P. Germination and Growth of Atriplex prostrata and Plantago coronopus: Two Strategies to Survive in Saline Habitats. Flora 2017, 227, 56-63. [CrossRef]

184. Rodrigues, M.; Gangadhar, K.; Vizetto-Duarte, C.; Wubshet, S.; Nyberg, N.; Barreira, L.; Varela, J.; Custódio, L. Maritime Halophyte Species from Southern Portugal as Sources of Bioactive Molecules. Mar. Drugs 2014, 12, 2228-2244. [CrossRef]

185. Benzarti, M.; ben Rejeb, K.; Debez, A.; Messedi, D.; Abdelly, C. Photosynthetic Activity and Leaf Antioxidative Responses of Atriplex portulacoides Subjected to Extreme Salinity. Acta Physiol. Plant 2012, 34, 1679-1688. [CrossRef]

186. Maciel, E.; Lillebø, A.; Domingues, P.; da Costa, E.; Calado, R.; Domingues, M.R.M. Polar Lipidome Profiling of Salicornia ramosissima and Halimione portulacoides and the Relevance of Lipidomics for the Valorization of Halophytes. Phytochemistry 2018, 153, 94-101. [CrossRef] [PubMed]

187. Sousa, A.I.; Caçador, I.; Lillebø, A.I.; Pardal, M.A. Heavy Metal Accumulation in Halimione portulacoides: Intra- and Extra-Cellular Metal Binding Sites. Chemosphere 2008, 70, 850-857. [CrossRef] [PubMed]

188. Dickinson, C.H. The Mycoflora Associated with Halimione portulacoides: III. fungi on green and moribund leaves. Trans. Br. Mycol. Soc. 1965, 48, 381-390. [CrossRef]

189. Dickinson, C.H.; Pugh, G.J.F. The Mycoflora Associated with Halimione Portulacoides: II. Root surface fungi of mature and excised plants. Trans. Br. Mycol. Soc. 1965, 48, 595-602. [CrossRef]

190. Aleixo, A.M.F. Biodiversidade de Fungos Endofíticos Em Halimione portulacoides. Master's Thesis, Departamento de Biologia da Universidade de Aveiro, Aveiro, Portugal, 2013.

191. Morales, P.; Ferreira, I.C.F.R.; Carvalho, A.M.; Sánchez-Mata, M.C.; Cámara, M.; Fernández-Ruiz, V.; Pardo-de-Santayana, M.; Tardío, J. Mediterranean Non-Cultivated Vegetables as Dietary Sources of Compounds with Antioxidant and Biological Activity. LWT-Food Sci. Technol. 2014, 55, 389-396. [CrossRef]

192. Niazi, B.H.; Athar, M.; Salim, M.; Rozema, J. Growth and Ionic Relations of Fodderbeet and Seabeet under Saline Environments. Int. J. Environ. Sci. Technol. 2005, 2, 113-120. [CrossRef]

193. Zardi-Bergaoui, A.; ben Nejma, A.; Harzallah-Skhiri, F.; Flamini, G.; Ascrizzi, R.; ben Jannet, H. Chemical Composition and Biological Studies of the Essential Oil from Aerial Parts of Beta vulgaris subsp. maritima (L.) Arcang. Growing in Tunisia. Chem. Biodivers. 2017, 14, e1700234. [CrossRef]

194. Arbelet-Bonnin, D.; Blasselle, C.; Rose Palm, E.; Redwan, M.; Ponnaiah, M.; Laurenti, P.; Meimoun, P.; Gilard, F.; Gakière, B.; Mancuso, S.; et al. Metabolism Regulation during Salt Exposure in the Halophyte Cakile maritima. Environ. Exp. Bot. 2020, 177, 104075. [CrossRef]

195. Ellouzi, H.; ben Hamed, K.; Cela, J.; Munné-Bosch, S.; Abdelly, C. Early Effects of Salt Stress on the Physiological and Oxidative Status of Cakile maritima (Halophyte) and Arabidopsis thaliana (Glycophyte). Physiol. Plant 2011, 142, 128-143. [CrossRef]

196. Guil-Guerrero, J.L.; Giménez-Martínez, J.J.; Torija-Isasa, M.E. Nutritional Composition of Wild Edible Crucifer Species. J. Food Biochem. 1999, 23, 283-294. [CrossRef]

197. Welcome, A.K.; van Wyk, B.-E. An Inventory and Analysis of the Food Plants of Southern Africa. S. Afr. J. Bot. 2019, 122, 136-179. [CrossRef]

198. Kumar, A.; Sreedharan, S.; Singh, P.; Achigan-Dako, E.G.; Ramchiary, N. Improvement of a Traditional Orphan Food Crop, Portulaca oleracea L. (Purslane) Using Genomics for Sustainable Food Security and Climate-Resilient Agriculture. Front. Sustain. Food Syst. 2021, 5, 711820. [CrossRef]

199. Calvo, M.M.; Tzamourani, A.; Martínez-Alvarez, O. Halophytes as a Potential Source of Melanosis-Inhibiting Compounds. Mechanism of Inhibition of a Characterized Polyphenol Extract of Purslane (Portulaca oleracea). Food Chem. 2021, 355, 129649. [CrossRef] 
200. Mandlaa; Zhang, Y.; Wan, Y.; Tie, Y.; Zhang, B.; Wang, R.; Wang, G. Isolation and Characterization of Endophytic Fungi from Purslane and the Effects of Isolates on the Growth of the Host. Adv. Microbiol. 2019, 9, 438-453. [CrossRef]

201. Abdel-Sater, M.A.; Abdel-Latif, A.M.A.; Abdel-Wahab, D.A.; Al-Bedak, O.A. Endophytic Mycobiota of Wild Medicinal Plants from New Valley Governorate, Egypt and Quantitative Assessment of Their Cell Wall Degrading Enzymes. Stud. Fungi 2021, 6, 78-91. [CrossRef] 